Published in final edited form as:

Heart Fail Clin. 2012 October ; 8(4): 589-607. doi:10.1016/j.hfc.2012.06.012.

\title{
Role of Lipotoxicity in Endothelial Dysfunction
}

\author{
Jeong-a Kim, $\mathrm{PhD}^{\mathrm{a}, \mathrm{b}}$, Monica Montagnani, $\mathrm{MD}, \mathrm{PhD}^{\mathrm{c}}$, Sruti Chandrasekran, $\mathrm{MD}^{\mathrm{d}}$, and \\ Michael J. Quon, MD, PhDd, ${ }^{*}$ \\ aDivision of Endocrinology, Diabetes, and Metabolism, Department of Medicine, UAB \\ Comprehensive Diabetes Center, University of Alabama at Birmingham, 1808 7th Avenue South, \\ BDB 777, Birmingham, AL 35294-0012, USA

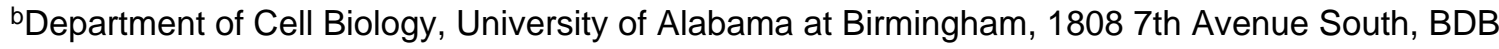 \\ 777, Birmingham, AL 35294, USA \\ 'Department of Biomedical Sciences and Human Oncology, Pharmacology Section, University \\ "Aldo Moro" at Bari, Policlinico, Piazza G. Cesare, 11, 70124 Bari, Italy \\ ${ }^{d}$ Department of Medicine, Division of Endocrinology, Diabetes \& Nutrition, University of Maryland \\ at Baltimore, 660 West Redwood Street, HH 495, Baltimore, MD 21201, USA
}

\section{SUMMARY}

Lipotoxicity, caused in large part by overnutrition, directly leads to endothelial dysfunction.

Excess lipids in both the circulation and at the tissue level contribute to endothelial dysfunction that underlies much of the pathophysiology of both metabolic disease, including obesity and diabetes and their CV complications. Direct lipotoxic effects on other organs as well as secondary insults from endothelial dysfunction synergize to cause substantial morbidity and mortality. Lifestyle interventions, including reduced calorie intake, diet, and exercise as well as a variety of pharmacologic interventions targeting various mechanisms underlying lipotoxicity in vascular endothelium significantly modify metabolic and CV risk.

\section{Keywords}

Lipotoxicity; Endothelial dysfunction; Metabolic disorders; Cardiovascular disease

\section{INTRODUCTION}

CV disease is the leading cause of death in the United States. Reciprocal relationships between endothelial dysfunction and insulin resistance tightly link metabolic diseases, including obesity and diabetes, with their $\mathrm{CV}$ complications. ${ }^{1}$ Obesity and diabetes per se increase the risk of $\mathrm{CV}$ morbidity and mortality at least 3 -fold. ${ }^{2}$

Vascular endothelium plays an important role in maintaining vascular homeostasis and actively participates in the delivery of hormones, nutrients, and oxygen to metabolic target

(C) 2012 Elsevier Inc. All rights reserved.

*Corresponding author: quonm@ medicine.umaryland.edu. 
tissues. These functions are regulated by secretion of endothelium-dependent relaxing factors, endothelium-dependent hyperpolarizing factors, and endothelium-dependent contracting factors. ${ }^{3}$ Imbalance among these factors contributes to endothelial dysfunction that is associated with cardiac dysfunction, coronary artery disease, hypertension, diabetes, and neurologic disorders, leading to increased mortality and morbidity. ${ }^{1,4}$ Excess circulating lipids (hyperlipidemia) caused by both overnutrition and disordered metabolism are important independent cause of both endothelial dysfunction and insulin resistance. High levels of lipids, including triglycerides (TGs), NEFAs, and low-density lipoprotein cholesterol (LDL-C) damage vascular tissues and their functions. This is known as lipotoxicity ${ }^{5-7}$ Lipotoxicity may be defined as pathologic changes at the cellular and organ levels that results from excess lipids in the circulation or in tissues.

Endothelial dysfunction caused by lipotoxicity is mediated through several diverse mechanisms that include increased oxidative stress and proinflammatory responses. The effect of lipotoxicity on endothelial dysfunction is magnified even further in patients with obesity, metabolic syndrome, and diabetes. ${ }^{1,8,9}$ This article discusses

1. Lipotoxic effects in vascular endothelium

2. Molecular mechanisms underlying the pathophysiology of endothelial dysfunction from lipotoxicity

3. Lifestyle intervention and therapeutic approaches that may oppose lipotoxicityinduced endothelial dysfunction and its $\mathrm{CV}$ and metabolic complications.

\section{HYPERLIPIDEMIA AND ENDOTHELIAL DYSFUNCTION}

\section{Triglycerides}

An elevated serum TG level is a risk factor for coronary heart disease. ${ }^{10,11}$ Lipoproteinassociated TGs circulate in the plasma as very low-density lipoproteins or chylomicrons. Insulin receptor substrate-1 (IRS-1) knockout mice, a nonobese animal model of insulin resistance, have impairments in endothelium-dependent vascular relaxation and hypertriglyceridemia (HTG) with low activity of lipoprotein lipase (LPL). ${ }^{12}$ This suggests that insulin resistance may play an important role in hypertriglyceridemia and endothelial dysfunction that may accelerate the progression of atherosclerosis. Through genome-wide association studies, Johansen and colleagues ${ }^{13}$ identified common variants in APOA5, Glucokinase regulator, LPL, and APOB that are associated with HTG. Mutations of lipoproteins, LPL and glycosylphosphatidylinositol-anchored high-density lipoproteinbinding protein 1 (GP1HBP1) are associated with HTG. ${ }^{14,15}$ LPL hydrolyzes TGs into glycerol and free fatty acids (FFAs). GP1HBP1 is necessary for TG hydrolysis. ${ }^{16}$ In addition to genetic variations, diet, lack of exercise, and various medications affect HTG. ${ }^{17}$ Lipodystrophy, Cushing syndrome, and medications, including $\beta$-blockers and tamoxifen, induce HTG. ${ }^{18}$ A meta-analysis of population-based prospective studies shows that plasma TG level is a risk factor for CV disease independent of high-density lipoprotein (HDL). ${ }^{19}$ The TG level associated with postprandial lipemia suppresses flow-mediated dilation in patients with hypothyroidism. ${ }^{20}$ Flow-mediated dilation is negatively correlated with TG and thiobarbituric acid reactive substances level in the plasma. Thus, endothelial dysfunction 
after an oral fat challenge in these patients is due to HTG and reactive oxygen species. ${ }^{20} \mathrm{~A}$ clinical study with 109 patients who had coronary heart disease during statin therapy compared ezetimibe add-on therapy to placebo. Endothelial function was assessed after 3 months. Flow-mediated dilation in patients treated with ezetimibe is improved and blood TG level is significantly reduced. ${ }^{21}$ Ezetimibe improves postprandial hyperlipidemia and endothelial dysfunction. ${ }^{22}$ In a previous report, the intima-media thickness of patients who received combination therapy of ezetimibe and simvastatin is not different from that in the patients treated with simvastatin only despite significant lowering effect of low-density lipoprotein (LDL), as shown in the Ezetimibe and Simvastatin in Hypercholesterolemia Enhances Atherosclerosis Regression trial. ${ }^{23}$ This suggests that TG level independent of LDL may lead to endothelial dysfunction that contributes to development of atherosclerosis. TG increases inflammatory responses by activation of leukocytes. ${ }^{24-26}$ Intramuscular TG content is also associated with insulin resistance in skeletal muscle ${ }^{27,28}$ and endothelial dysfunction. ${ }^{29}$ Accumulation of TG in the heart is associated with heart failure in animals and humans. ${ }^{30,31}$ Thus, intracellular and plasma level of TG is associated with impairment of glucose tolerance and insulin resistance as well as CV dysfunction.

\section{Nonesterified Fatty Acids}

Increased plasma NEFAs and accelerated rates of lipolysis are characteristics of type 2 diabetes mellitus and obesity. ${ }^{32-34}$ Acute elevation of plasma fatty acids leads to impairment of glucose uptake, ${ }^{35}$ inhibition of hepatic gluconeogenesis, ${ }^{36,37}$ and endothelial dysfunction..$^{38,39}$ Inhibition of lipolysis by using acipimox, a niacin derivative, improves glucose tolerance, insulin sensitivity, insulin-stimulated capillary recruitment, and acetylcholine-stimulated vasodilation. ${ }^{40,41}$ Likewise, intralipid plus heparin impairs $20 \%$ of methacholine, but not single-nucleotide polymorphism-stimulated, vasodilation in lean healthy human subjects. ${ }^{39}$ This suggests that fasting NEFA impairs glucose metabolism as well as endothelial function. NEFA levels independently predict all-cause and CV mortality in subjects with angiographic coronary artery disease. ${ }^{42}$ Some other studies, however, ${ }^{43,44}$ show fasting NEFA levels were not correlated with obesity when normalized to fat mass. ${ }^{45}$ NEFA is liberated from adipose tissue under starvation conditions by hydrolysis of TG. Elevated fasting NEFA level is associated with obesity. ${ }^{46}$ After a meal, dietary fat is hydrolyzed by LPL to NEFA and glycerol that are taken up by adipose tissue and reesterified intracellularly. Some NEFA escapes, however, in a process called spillover. ${ }^{47} \mathrm{~A}$ recent study shows that rates of delivery of NEFA were reduced in obese men compared with lean subjects when normalized to fat mass. The reduced lipid trafficking into adipose tissue leads to ectopic fat deposition. ${ }^{48}$ Thus, postprandial fat content is determined by dietary fat, $40 \%$ to $50 \%$ of which may be from spillover. ${ }^{48}$ Both fasting and postprandial NEFAs interact with glucose metabolism; NEFA level may be a predictor for CV disease that is associated with obesity and diabetes.

\section{Cholesterol}

Non-HDL cholesterol contributes to impairment of nitric oxide (NO) bioavailability due to increased production of reactive oxygen species and inhibition of endothelial NO synthase (eNOS) activity that leads to endothelial dysfunction and atherosclerosis. ${ }^{49-51}$ Patients with high cholesterol have impaired endothelium-dependent vasodilation but not endothelial 
independent vasodilation. ${ }^{50}$ This suggests that elevated cholesterol levels impair vascular function, which contributes to atherosclerosis. Plasma LDL levels in patients with type 2 diabetes mellitus are similar to those of nondiabetics, but LDL catabolism is significantly reduced. ${ }^{52}$ Insulin treatment in type 2 diabetes mellitus and lipid lowering by diet or pharmacologic treatments, including statins, restores catabolism of LDL ${ }^{52,53}$ and improves endothelial function. ${ }^{54}$ Oxidized LDL (ox-LDL)/LDL-C ratio in type 2 diabetes mellitus is reduced by insulin therapy. ${ }^{55} \mathrm{Ox}$-LDL displaces eNOS from caveolae to impair eNOS activity stimulated by acetylcholine. ${ }^{56}$ Ox-LDL-mediated inhibition of eNOS is restored by HDL. ${ }^{57}$ Ox-LDL is taken up by macrophages to promote foam cell formation and reduces cholesterol efflux and reverse cholesterol transport. ${ }^{58,59}$ These processes contribute to atherosclerosis and CV diseases. A decreased HDL level is associated with obesity and HTG, insulin resistance and diabetes that may be due to increased HDL catabolism. ${ }^{60-62}$ In a more recent study, HDL isolated from patients with CAD fails to activate eNOS and does not have anti-inflammatory and endothelial repair activity when compared with HDL isolated from healthy subjects. ${ }^{63}$ HDL isolated from patients with type 2 diabetes mellitus is not able to reverse the ox-LDL-mediated inhibition of endothelium-dependent vasorelaxation. ${ }^{64}$ This suggests not all HDL is beneficial. Thus, deregulated cholesterol metabolism affects endothelial function and blood flow that contributes to atherosclerosis and $\mathrm{CV}$ events.

\section{LIPOTOXICITY IN TISSUES}

\section{Cardiomyopathy}

Obesity, insulin resistance, and diabetes are associated with cardiomyopathy that leads to premature morbidity and mortality. Obesity-mediated endothelial dysfunction, dysregulated autonomic regulation, and altered hormonal profiles contribute to the impairment of cardiac function. ${ }^{65-67}$ Obese people have 2 to 3 times higher risk for developing heart failure than normal weight people. ${ }^{68}$ Excess lipid intake or dyslipidemia causes ectopic lipid accumulation in cardiomyocytes. This results in cell death, increased ER stress, mitochondrial dysfunction, accumulation of ceramide, and increased exposure to reactive oxygen species. ${ }^{69}$ Accumulation of TG in myocytes results in alternative substrate metabolism. Thus, cardiac energy metabolism is shifted toward more $\mathrm{O}_{2}$ consumption and lower ATP production that leads to cardiac dysfunction. Ceramide metabolized from FFA is a major mediator of lipotoxicity that is blocked by myriocin or by stimulation of sphingomyelinase. ${ }^{69,70}$ Dietary fat determines lipid profiles in the plasma and tissues and causes various pathophysiologic conditions. In recent studies, a diet with high fat/low carbohydrate is more preventive in progression of heart failure than a diet with low fat/high carbohydrate. ${ }^{71-75}$ A diet high in polyunsaturated fatty acid reduces coronary heart disease, whereas a diet with high cholesterol increases coronary heart disease. ${ }^{76-79}$ Studies using various high fat diet and rodent models are well described in a recent review. ${ }^{75}$ More studies regarding recommendations for optimal diet to patients with cardiomyopathy are necessary.

\section{Nephropathy}

Nephrotic subjects tend to develop CV disease associated with metabolic disorders and vascular complications. Diabetic nephropathy is a major risk factor for $\mathrm{CV}$ disease and 
increases morbidity and mortality. ${ }^{80}$ Diabetic nephropathy progresses in 5 stages: glomerular hyperfiltration, incipient nephropathy, microalbuminuria, overt proteinuria, and end-stage renal disease. ${ }^{81}$ Endothelial dysfunction precedes manifestation of microalbuminuria and is an independent risk factor for $\mathrm{CV}$ disease and diabetic nephropathy. ${ }^{82,83}$ Hypercholesterolemia decreases NO availability, which leads to activation of podocyte and renal injury. ${ }^{84,85}$ The common lipid abnormalities found in chronic kidney disease patients are HTG, reduced HDL, and increased lipoprotein (a). ${ }^{86}$ Lipoprotein (a) level is a risk factor for CVD and is associated with glomerular filtration rate. ${ }^{87}$ Decreased catabolism of very low-density lipoproteins, chylomicrons, and their remnants leads to accumulation in the plasma. Increased ApoC(III), a potent inhibitor of LPL, leads to increased serum TG. ${ }^{88}$ Proposed mechanisms include increased reabsorption of lipids, including, fatty acids, phospholipids, and cholesterol, that stimulates tubulointerstitial inflammation and tissue injury. ${ }^{89,90}$ Accumulation of oxidized lipoproteins, especially oxLDL, causes inflammation in glomerular mesangium that contributes to recruitment of macrophages. ${ }^{91,92}$ Diabetic nephropathy can contribute to dyslipidemia and lipid-lowering therapies that can improve endothelial function may have beneficial effects on both renal and $\mathrm{CV}$ functions.

\section{Neuropathy}

Patients with diabetic neuropathy have peripheral nerve disorders with symptoms of pain, numbness, weakness, and difficulties with balance. ${ }^{93,94}$ It is characterized as axonopathy with distal predominance, with axons failing to regenerate. ${ }^{95}$ Both myelinated and unmyelinated fibers undergo axonal change, leading to axonopathy. ${ }^{95}$ Impaired autonomic nerve functions inducing a reduction of blood flow contributes to alterations in the microvasculature, leading to diabetic nephropathy and retinopathy. ${ }^{96,97}$ Impairment of vascular function is associated with diabetic neuropathy and CV disease. ${ }^{98,99}$ Loss of autonomic control is associated with impairment of ventricular function independently from endothelial dysfunction. ${ }^{100}$ Accumulation of sorbitol, oxidized lipid, and poly (ADP-ribose) polymerase (PARP) and activation of lipoxygenase in peripheral nerve are observed in a high-fat diet rodent model. ${ }^{101}$ FFA causes toxicity in cultured neuronal and Schwann cell lines. ${ }^{102}$ Elevated FFAs due to increased lipolysis in adipocytes may increase secretion of inflammatory cytokines affecting peripheral nerve inflammation. Neuronal cells express receptorsfor ox-LDL and glycated LDL, including ox-LDL receptor 1, scavenger receptors, receptor for advanced glycation end products, and Toll-like receptors (TLRs). ${ }^{103,104}$ This suggests that ox-LDL and glycated LDL can injure neuronal cells through stimulation of inflammatory response and oxidative stress. ${ }^{103}$ Dysregulated lipids directly and indirectly impair neuronal function through mediators, including inflammatory cytokines and active oxygen/nitrogen species produced by other tissues that contribute to neuropathy.

\section{MOLECULAR MECHANISMS}

Lipid-mediated toxicities contribute to functional abnormalities in various tissues, including vascular endothelium, cardiac, and renal tissues. The proposed mechanisms are

- Oxidative stress 
- Inflammation

- Mitochondrial dysfunction

- $\quad$ ER stress

- Cell death

These mechanisms are interlinked and contribute to complex pathophysiology.

\section{Oxidative Stress}

Increased lipids in the plasma, ectopic lipid accumulation, and intracellular lipid droplets cause oxidative stress. ${ }^{27,105}$ Reactive oxygen and nitrogen species react with proteins, lipid, and carbohydrates to modify structure and function of cellular components. ${ }^{106,107}$ Lipids affect cellular redox status through metabolic pathways. Vascular endothelium is an important redox-sensitive tissue because it transports various metabolites between tissues. Nicotinamide adenine dinucleotide phosphate-oxidase (NAD(P)H oxidase) creates oxidative stress by producing superoxide that can be converted to hydrogen peroxide and reacts with NO. ${ }^{108-110}$ This reaction determines bioavailability of NO, a major determinant of endothelial dysfunction. ${ }^{109}$ In the Zucker fatty rat, plasma FFA and TG levels are higher than lean controls causing impairment of acetylcholine-stimulated vasodilation. ${ }^{111}$ Treatment of primary vascular endothelial cells with palmitate stimulates production of superoxide and increased expression of NAD(P)H oxidase subunits. ${ }^{109,111}$ Inhibition of NADP oxidase activity with apocynin or dipenyle-neiodine or by knockdown of NAD(P)H oxidase (NOX) 4 (a NOX subunit) suppresses production of superoxide or expression of $\mathrm{NAD}(\mathrm{P}) \mathrm{H}$ oxidase subunits. These data suggest that saturated fatty acids stimulate production of reactive oxygen species that leads to reduction of NO, bioavailability, and subsequent endothelial dysfunction. In addition to increased expression of $\mathrm{NAD}(\mathrm{P}) \mathrm{H}$ oxidase subunits, diacylglycerol stimulates activation of protein kinase $\mathrm{C}$, a kinase that phosphorylates p47phox. Phosphorylation of $\mathrm{p} 47 \mathrm{phox}$ is important for the activation of $\mathrm{NAD}(\mathrm{P}) \mathrm{H}$ oxidase and assembly of multiple $\mathrm{NAD}(\mathrm{P}) \mathrm{H}$ oxidase subunits to form an NAD(P)H oxidase holoenzyme. ${ }^{12,113}$ Another mechanism to increase oxidative stress requires mitochondrial dysfunction. The mitochondrial respiratory chain (mainly complex I and III) produces superoxide when fatty acids are oxidized. ${ }^{114,115}$ Fatty acids are metabolized by $\beta$-oxidation to produce NADH (Nicotinamide adenin dinucleotide) and $\mathrm{FADH}_{2}$ (Flavin adenin dinucleotide) that enter the electron transport chain. This generates ATP by oxidative phosphorylation in mitochondria, where oxygen serves as an electron acceptor. During this process, a proton gradient is formed across the mitochondrial membrane where addition of a single electron to oxygen generates superoxide. ${ }^{114,116,117}$ Accumulated protons leak from the intermembrane space to the matrix, resulting in reduced proton motive force that generates heat instead of ATP. This is called uncoupling. Uncoupling protein 2 knockout mice have increased diet-induced atherosclerosis, endothelial dysfunction, and decreased antioxidative capacity. ${ }^{118}$ Additionally, uncoupling of eNOS and stimulation of xanthine oxidase produces superoxide. ${ }^{119-121}$ Increased reactive oxygen species increases lipid peroxidation and oxidized cholesterol and reduces NO availability to promote vascular insulin resistance and endothelial dysfunction. 


\section{Inflammation}

Obesity and type 2 diabetes mellitus are characterized by a chronic proinflammatory state. ${ }^{122,123}$ Increased plasma or intracellular lipid contents cause proinflammatory responses. Inflammation is closely linked to atherosclerosis, a major sequelae of dyslipidemia-mediated endothelial dysfunction. ${ }^{124}$ NEFA stimulates TLRs $2 / 4$ that activate Ikappa B kinase (IKK $\beta$ )/nuclear factor (NF)- $\kappa \mathrm{B}$ and c-Jun N-terminal kinase (JNK)/ activator protein-1, pathways leading to increased expression of other cytokines and cell adhesion molecules, including tumor necrosis factor (TNF)-a, interleukin (IL)-1 $\beta$, intercellular adhesion molecule, vascular cell adhesion molecule, and E-selectin in endothelial cells. ${ }^{125}$ NEFA-mediated proinflammatory signaling inhibits insulin signaling that leads to impairment of glucose tolerance, vascular insulin resistance, and lipogenesis. ${ }^{125-127}$ Activation of TLRs by NEFA occurs in macrophages to facilitate atherogenic processes that exacerbate pathophysiology in metabolic and CV tissues. ${ }^{128}$ NEFA activates bone morphogenic proteins 2 and 4 that contribute to vascular calcification and differentiation of smooth muscle cells associated with vascular stiffness. ${ }^{109,129}$ Ox-LDL also acts as a ligand for TLRs to stimulate proinflammatory responses. ${ }^{130}$ The mechanisms for inflammatory signaling to inhibit insulin signaling are increased serine phosphorylation of IRS- 1 and IRS-2, facilitated degradation of IRS- 1 and IRS-2, and ceramide production. ${ }^{131}$ Increased serine phosphorylation of IRS-1 and IRS-2 leads to inhibition of interaction with insulin receptor, plasma membrane, and phosphatidylinositol 3-kinases that are linked to reduced activation of Akt and impairment of eNOS activation. ${ }^{132-135}$ This mechanism contributes to impairment of glucose uptake and blood flow in skeletal muscle. ${ }^{38,119,136}$ Activation of TLRs by NEFA or LPS increases ceramide production that contributes to inhibition of insulin-stimulated phosphorylation of Akt as well as facilitation of apoptosis. ${ }^{131,137}$

\section{Mitochondrial Dysfunction}

Mitochondria are intracellular organelles that oxidize fatty acid. Electron transfer from $\mathrm{NAD}(\mathrm{P}) \mathrm{H}$ to $\mathrm{NAD}(\mathrm{P})^{+}$couples with production of ATP, an energy source for movement and cellular enzymatic process. ${ }^{117}$ When metabolic stress conditions occur, cells adapt by increasing mitochondrial biogenesis. ${ }^{138,139}$ More mitochondria may compensate for increased cellular energy needs. eNOS and NO play important roles in mitochondrial biogenesis through AMP-activated protein kinase (AMPK)/nuclear respiratory factor 1/ peroxisome proliferator-activated receptor (PPAR) $\gamma$ coactivator 1a (PGC1a)-mediated mechanisms. ${ }^{140,141}$ Maladaptation of this process leads to mitochondrial dysfunction and decreased ATP production. Thus, mitochondrial dysfunction is associated with decreased fat oxidation and accumulation of intramuscular lipids. ${ }^{142}$ Mitochondria also play important roles in apoptosis (discussed later).

\section{ER Stress}

Obesity and type 2 diabetes mellitus cause increased ER stress in animal models and humans. ${ }^{143-146}$ ER stress is involved in both impairment of energy metabolism and inflammation. ${ }^{147}$ The lipid peroxidation product, 4-hydroxy-trans-2 nonenal (HNE), increases ER stress. Treatment of endothelial cells with phenylbutric acid or taurine- 
conjugated ursodeoxycholic reduces HNE-induced leukocyte rolling and adhesion. ${ }^{148}$ ER stress leads to unfolded protein responses (UPRs) by (1) increasing expression of molecular chaperones, (2) facilitating degradation of proteins, and (3) inhibiting protein synthesis. ${ }^{147}$ Molecules in the ER, including ATF6, IRE-1a/XBP-1, and p-PERK/p-eIF2a, are involved in UPRs to protect cells from stress conditions. When UPR is insufficient to protect cells from ER stress, cells are subjected to pathologic conditions, including inflammation, apoptosis, and lipid accumulation, that promote atherogenesis. ${ }^{144,149-152}$ Activation of JNK is a well-known mechanism underlying obesity-induced insulin resistance and ER stress. ${ }^{143,144,153}$ JNK directly phosphorylates IRS-1 at serine 307 , leading to inhibition of insulin signaling pathways that contribute to inflammatory responses, impairment of glucose tolerance, and endothelial dysfunction. ${ }^{125,154-156}$

\section{Apoptosis}

Excess lipids increase ceramide, reactive oxygen species, lipid peroxidation, and membrane destabilization that lead to cell death through apoptosis. Inhibition of ceramide synthesis by myriocin reverses high fat/high cholesterol-mediated endothelial dysfunction and atherosclerosis. ${ }^{157}$ Antiapoptotic molecules, including Bcl2 and Bax, are phosphorylated by Akt. This action is inhibited by ceramide to cause apoptosis. ${ }^{158,159}$ Ceramide increases iNOS expression through NF- $\kappa \mathrm{B}$, leading to production of peroxinitrite that is toxic to cells. ${ }^{160,161}$ Ox-LDL promotes endothelial cell death and atherosclerosis. This is opposed by HDL and ApoA. ${ }^{162,163}$ Endothelial dysfunction and subsequent reduction of NO inhibits caspase activity by nitrosylation. ${ }^{164,165}$ Thus, tissue damage by lipotoxicity is a major mechanism underlying the pathophysiology caused by dyslipidemia and diabetes.

\section{ROLE OF EXERCISE IN OPPOSING LIPOTOXICITY AND ENDOTHELIAL DYSFUNCTION}

Exercise plays a pivotal role in improving lipotoxicity and endothelial dysfunction. ${ }^{166,167}$ Increased lipid accumulation with intramyocellular TGs in obese individuals with limited physical activity leads to reduced $\beta$-oxidation. Activation of peroxidation pathways predisposes to insulin resistance and its complications. ${ }^{168}$ Intermediates of peroxidation pathways (thiobarbituric acid derivative, 4-hydroxynonenol, and malondialdehyde) may lead to increased levels of TNF- $a$ and other proinflammatory factors that mediate insulin resistance and endothelial dysfunction. ${ }^{168}$ Exercise and endurance training help increase turnover of stored excess lipids by increasing $\beta$-oxidation and reducing peroxidation pathways. In one study, even low-intensity exercise of $2 \mathrm{~h} / \mathrm{wk}$ for 3 months had a positive impact on opposing lipotoxicity and increasing total fat oxidation. ${ }^{169}$ Exercise has beneficial effects not only on skeletal muscle lipotoxicity but also on cardiac muscle. Two weeks of intensive swimming by mice led to an increase in diacylglycerol acyltransferase expression with greater TG uptake and oxidation in cardiac muscle. This was accompanied by decreased plasma cholesterol, TG, FFA, ceramide, and diacylglycerol. Lipid uptake genes, CD36 and LPL; PDK4 (Pyruvate dehydrogenase kinas, isozyme4), a regulator of glucose oxidation and acyl coenzyme A oxidase; PPAR a mRNA; and mRNA for PGC1a (a regulator of mitochondrial biogenesis) increased with 2 weeks of physical activity. Adipose TG lipase, the enzyme that initiates intracellular TG lipolysis, was induced with exercise. ${ }^{170}$ 
The other benefits of exercise to oppose lipotoxicity include increased expression of superoxide dismutase. ${ }^{171,172}$ Oxidative enzyme activity in skeletal muscle improves with moderate intensity physical activity in previously sedentary men and women with 4 months of physical activity and moderate weight loss. Exercise improves enzymatic activity of the mitochondrial electron transport chain and increased surface area of the inner mitochondrial membrane with increased cardiolipin levels leading to mitochondrial biogenesis. ${ }^{173}$

AMPK is a fuel-sensing enzyme that is activated in response to exercise. It is also expressed in adipose tissue, liver, and other organs in response to exercise in intensity-dependent matter. Even low-intensity exercise, when prolonged, can also increase expression of AMPK. AMPK activity causes increased glucose uptake in muscle, promotes fatty acid oxidation, exerts anti-inflammatory and anti-fibrinolytic actions, raises HDL cholesterol, and decreases protein synthesis in skeletal muscle. AMPK also has central actions to decrease food intake in response to leptin action in the hypothalamus. ${ }^{174}$ Hypothalamic insulin and leptin sensitivity is also improved by anti-inflammatory effect of cytokines, IL-6 and IL-10, that are positively influenced by exercise. ${ }^{175}$ Other beneficial effects of exercise include increase in GLUT4 expression ${ }^{176}$ and effects on muscle glycogen synthase activity. These actions of exercise oppose lipotoxicity and translate into improved CV outcomes.

The effect of exercise to oppose endothelial dysfunction is mediated, in part, by increased bioavailability of NO in the vasculature. ${ }^{177}$ Regular physical activity improves blood glucose control and can prevent or delay type 2 diabetes mellitus, along with beneficial effects on blood pressure, lipids, CV morbidity, mortality, and quality of life. The American College of Sports Medicine and the American Diabetes Association recommend combined aerobic and resistance training exercise and aerobic activity of moderate intensity, $40 \%$ to $60 \%$ of $\mathrm{V} \mathrm{O}_{2}$ max, 3 days a week, with no more than 2 consecutive days between bouts of physical activity. ${ }^{178}$

\section{PHARMACOLOGIC TREATMENTS}

Endothelial function is an important predictor of clinical outcomes, especially in populations with high $\mathrm{CV}$ risk. Therefore, targeting established and modifiable risk factors for lipotoxicity and endothelial dysfunction is a rational primary strategy for preventing CV complications associated with dyslipidemias and insulin-resistance. Combined therapy with statins or PPAR agonists and renin-angiotensin-aldosterone system (RAAS) blockade has additive beneficial effects on endothelial dysfunction, dyslipidemia, and insulin resistance compared with monotherapy in patients with $\mathrm{CV}$ risk factors that are mediated through both distinct and interrelated mechanisms. ${ }^{179}$ In addition to primary prevention based on caloric restriction, weight loss, physical exercise, and smoking cessation, pharmacotherapies, including insulin sensitizers, hypolipidemic agents, and/or inhibitors of the renin-angiotensin system, effectively modify risk factors to result in beneficial effects on both metabolic and vascular homeostasis. A combinatorial therapeutic strategy aimed at improving circulating lipid profile, lowering oxidative stress, and attenuating inflammation by distinct cellular mechanisms may be helpful in improving the risk/benefit profile of pharmacotherapy for endothelial dysfunction. 


\section{Statins}

Statins comprise either natural or synthetic compounds (Box 1) acting as 3-hydroxy-3methylglutaryl coenzyme A (HMG-CoA) reductase inhibitors. HMG-CoA reductase converts HMG-CoA to mevalonic acid in the cholesterol biosynthetic pathway, the ratelimiting step in cholesterol synthesis. By inhibiting HGM-CoA reductase activity, statins decrease hepatic sterol synthesis. This decreases hepatocellular cholesterol. Hepatocytes respond to decreased intracellular cholesterol concentration by increasing synthesis of LDL receptors to enhance hepatic LDL reuptake from the circulation. The net result is an increased fractional catabolism of LDL that reduces serum LDL-C concentration and total cholesterol. ${ }^{180}$ Several large randomized controlled trials have unequivocally demonstrated that inhibition of HMG-CoA reductase with subsequent of lowering LDL-C has large beneficial impacts on CV risk. ${ }^{181-183}$ In addition to LDL lowering, statins have several pleiotropic effects associated with improvements in markers of vascular disease risk, including

- Inflammation

- Plaque stability

- Endothelial function ${ }^{184-188}$

\section{Box 1}

\section{Statins}

\section{Natural compounds}

- Lovastatin

- Simvastatin

- Pravastatin

\section{Synthetic compounds}

- Atorvastatin

- Fluvastatin

- Rosuvastatin

Direct actions of statins to affect Rho/Rho kinase pathways in human leukocytes have been reported. ${ }^{189,190}$ Several other in vitro and in vivo studies have suggested that statins exert physiologic effects independent from LDL cholesterol lowering. For example, beneficial vascular effects of statins may depend on their ability to modulate levels of C-reactive protein (CRP). CRP induces synthesis of cytokines, cell adhesion molecules, and tissue factor in monocytes and endothelial cells ${ }^{188,191}$ and upregulates angiotensin II type 1 (AT1) receptors in vascular smooth muscle cells. ${ }^{192}$ Therapy with statins decreases IL-1 $\beta$-induced plasma CRP levels independently of cholesterol lowering in transgenic mice expressing human CRP. ${ }^{193}$ These direct anti-inflammatory effects in vivo occur at the transcriptional level and have been confirmed in cultured human liver slices and in human hepatoma cells. ${ }^{193}$ Improved endothelial function in response to statins may also result from 
prevention of NO oxidation and upregulation of eNOS expression, ${ }^{194,195}$ partly by eNOS mRNA stabilization. ${ }^{196}$ Additional mechanisms by which statins exert their beneficial effects on endothelial function may involve eNOS coupling and vascular bioavailability of BH4 (tetrahydrobiopterin), a critical cofactor that is required to maintain eNOS enzymatic coupling activity. ${ }^{197,198}$ This effect has been attributed to statin-mediated upregulation of GTPCH I (guanosine triphosphate cyclohydrolase), the rate-limiting enzyme in BH4 biosynthesis, initially demonstrated in cultured human endothelial cells. ${ }^{199}$ Improved endothelial function in response to statin therapy has also been linked to increased NO and reduced peroxynitrite and $\mathrm{O}_{2}{ }^{-}$generation in cell culture ${ }^{198,200,201}$ as well as in animal models. ${ }^{202}$ Clinical evidence supports the concept that improved endothelial function with treatment with statins is associated with early reduction of systemic oxidative stress, ${ }^{203}$ partly as a result of reduction in NOX activity in the arterial wall. ${ }^{204}$ In addition, statins are known to downregulate AT1 receptor density, ${ }^{205}$ and this may result in a direct NOX inhibitory action through blockade of Rac isoprenylation.

\section{PPAR Agonists}

The nuclear receptor transcription factors, PPARs, including PPARa, PPAR $\gamma$, and PPAR $\beta / \delta$ isotypes, are each encoded by separate genes. PPARs are established drug targets for treating dyslipidemia and diabetes. ${ }^{206}$ PPARa agonists (fenofibrate, gemfibrozil, ciprofibrate, and clofibrate), PPAR $\gamma$ agonists (pioglitazone and rosiglitazone), ${ }^{207}$ and dual or pan agonists (bezafibrate, muraglitazar, ragaglitazar, tesaglitazar, and aleglitazar) ${ }^{208}$ have both metabolic and CV actions.

\section{Fibrates}

Although peroxisome proliferation does not occur in humans, fibrate drugs, which lower TGs and raise HDL, were found to do so via PPARa activation. ${ }^{209}$ Subsequent studies established that PPARa activation induces expression of LPL that releases fatty acids from TGs and represses apolipoprotein ApoC(III), an endogenous LPL inhibitor. PPARa increases expression of CD36, which participates in fatty acid uptake, and fatty acid binding proteins involved in fatty acid delivery. PPARa also regulates multiple enzymes involved in $\beta$-oxidation of fatty acids. PPARa activation also induces expression of APOA1, a major constituent of HDL. Fibrate therapy may help limit inflammatory responses induced by FFA in vascular and inflammatory cells. In endothelial cells, PPARa activated by synthetic agonists or LPL-mediated release of natural ligands inhibits adhesion molecule expression. ${ }^{210,211}$ Additional effects include suppression of monocyte-macrophage migration 212 and monocyte chemoattractant protein- 1 and reduced inflammatory markers, including CRP, lipoprotein-associated phospholipase $\mathrm{A}_{2}$, IL-6, fibrinogen, and TNF-a. ${ }^{213}$ PPARa activation also limits inflammation in vascular smooth muscle cells that may indirectly influence atherosclerosis. PPARa activation represses inflammation by inhibiting key proximal inflammatory mediators, including NF- $\kappa \mathrm{B}$ and activator protein-1. In vascular smooth muscle cells, PPARa also limits cellular proliferation by targeting the cyclindependent kinase inhibitor and tumor suppressor, $\mathrm{p} 16^{\mathrm{InK} 4 \mathrm{a}}$, resulting in inhibition of retinoblastoma protein phosphorylation, decreased $\mathrm{G}_{1}$ phase to $S$ phase transition, and less intimal hyperplasia in vivo. In macrophages, activation of PPARa decreases coagulation proteins and promotes cholesterol efflux, ${ }^{214}$ conferring additional protection from 
atherosclerosis. ${ }^{215}$ In addition, fibrates may decrease angiotensin II-mediated oxidative stress and inflammation in the vascular wall. ${ }^{216}$ Furthermore, fibrates may improve endothelial function indirectly via increased adiponectin levels and improved insulin sensitivity and flow-mediated vasodilation. ${ }^{217}$

Despite increasing in vitro evidence of vascular protective properties, fibrates have shown controversial results in the clinical setting: in the Veterans Affairs High-Density Lipoprotein Intervention Trial, gemfibrozil was shown to exert a statistically significant $22 \%$ relative risk reduction in $\mathrm{CV}$ events in a subgroup of patients with established heart disease and concomitant glucose intolerance or high fasting plasma insulin level. ${ }^{218,219}$ A subsequent study, the Fenofibrate Intervention and Event Lowering in Diabetes trial, did not find any significant difference in the primary endpoint between groups, although treatment with fenofibrate was associated with reduced secondary CV endpoints. ${ }^{220}$ The Action to Control Cardiovascular Risk in Diabetes, lipid arm, study reported that combining a statin and fenofibrate was no better in decreasing $\mathrm{CV}$ events than a statin alone. ${ }^{221}$ As suggested in other fibrate trials, however, a benefit was seen in the subgroup with more significantly elevated TG levels and lower HDL levels. ${ }^{222}$ The absence of trials focusing on patients with more significantly elevated TGs and lower HDL levels where fibrates may be most helpful, may help to resolve this issue.

\section{Thiazolidinediones}

Synthetic PPAR $\gamma$ receptor agonists ameliorate lipotoxicity by multiple mechanisms. These include a decrease of circulating NEFAs by inhibition of lipolysis, ${ }^{223,224}$ reduction of muscle long-chain fatty acylcoenzyme Alevels, ${ }^{225,226}$ and are distribution of fat and changes in body composition. ${ }^{5}$ Thiazolidinediones (TZDs) also ameliorate lipotoxicity and endothelial dysfunction via effects mediated through increased plasma adiponectin levels 227 and subsequent adiponectin-mediated antiatherogenic effects. ${ }^{228,229}$ More recently, beneficial effects of TZDs have been related to their ability to ameliorate mitochondrial lipotoxicity, a condition characterized by reduced expression of multiple nuclear genes that encode enzymes involved in oxidative metabolism, such as PGC1, ${ }^{34}$ a master regulator of mitochondrial biogenesis. ${ }^{230}$ Treatment with TZDs upregulates PGC1a and PGC1 $\beta$ mRNA expression in association with increased expression of pyruvate dehydrogenase alpha 1 and other mitochondrial oxidative phosphorylation genes. ${ }^{231}$ In addition to effects on lipid metabolism, TZDs may directly regulate multiple target genes relevant to inflammation and atherosclerosis. ${ }^{232}$ In vascular tissues, PPAR $\gamma$ regulates production of endothelial mediators, including $\mathrm{NO},{ }^{233}$ and modulates expression of genes involved in cell adhesion, ${ }^{234}$ inflammation, ${ }^{235}$ oxidative stress, ${ }^{236}$ and vasoconstriction. ${ }^{237,238}$ In macrophages, PPAR $\gamma$ anti-inflammatory actions play a protective role in atherosclerosis. ${ }^{214}$ In the vascular compartment, PPAR $\gamma$ ligands reduce AT1 receptor mRNA and protein expression, ${ }^{239}$ with decreases in reactive oxygen species and NADP oxidase activity as well as responsiveness to angiotensin II. These beneficial cellular and molecular properties of TZDs are not always supported by results from clinical trials. For example, effects of pioglitazone on CV events were investigated in PROactive, a large prospective study designed to test possible glucoseindependent CV benefits in patients undergoing TZDs therapy. ${ }^{240}$ Although only a nonstatistically significant trend toward benefit was seen with pioglitazone for multiple 
primary endpoints (10\% risk reduction), a $16 \%$ reduction was found when more standard, objective secondary endpoints, such as myocardial infarction, stroke, and CV mortality, were evaluated. ${ }^{240}$ In addition, pioglitazone decreased plaque volume in human coronaries $^{241}$ and carotid intima-media thickness. ${ }^{242}$ It is possible that these improvements may be related to pioglitazone-mediated increases in HDL. ${ }^{243,244}$ The effects of rosiglitazone on $\mathrm{CV}$ disease have been more controversial, partly because no large prospective study on CV outcomes was undertaken with this agent. Several meta-analyses of rosiglitazone data, including one by its manufacturer, suggest a possible increased risk of $\mathrm{CV}$ events, although the magnitude of this risk has been debated. ${ }^{245-247}$ Potential insight into the different clinical responses of PPAR $\gamma$ agonists may come from their structure/ activity relationship: as a consequence of their specific binding to the large PPAR $\gamma /$ retinoid $\mathrm{X}$ receptor nuclear complex, TZDs may have differing transcriptional effects resulting in differences in accessory molecule recruitment and/or release. ${ }^{247}$ For instance, pioglitazone lowers TGs, whereas rosiglitazone does not. ${ }^{248}$

\section{Dual PPAR Agonists}

There is significant interest in designing molecules that target 2 or more PPAR isoforms to combine insulin-sensitizing properties with TG-lowering/ HDL-raising effects. Dual or pan PPAR ligands include compounds such as tesaglitazar, muraglitazar, and aleglitazar. ${ }^{249}$ Muraglitazar prevents the onset of diabetes and its complications in $\mathrm{db} / \mathrm{db}$ mice ${ }^{250}$ and reduces hemoglobin $\mathrm{A}_{1 \mathrm{C}}$ and improves lipid profiles in diabetic patients. ${ }^{251}$ Another dual PPAR modulator, tesaglitazar, reduces atherosclerosis in mice with LDL receptor deficiency, ${ }^{252}$ improves metabolic abnormalities and renal function, decreases blood pressure, and prevents glomerular and interstitial lesions in obese Zucker rats ${ }^{253}$ and $\mathrm{db} / \mathrm{db}$ mice. ${ }^{254}$ Tesaglitazar suppresses both hyperglycemia and dyslipidemia in diabetic patients. ${ }^{255}$ Chiglitazar improves impaired insulin and glucose tolerance and decreases plasma TG, total cholesterol, NEFAs, and LDL-C levels in animal models of obesity. ${ }^{256}$ Despite promising animal studies and positive clinical intervention trials, use and testing of several dual/pan PPAR modulators in humans have been discontinued because of severe side effects, including renal failure, fibrosarcomas, urinary cancer, and anemia. Aleglitazar is the only dual-PPARa/ $\gamma$ agonist currently in late-stage development. ${ }^{206,257} \mathrm{~A}$ large prospective $\mathrm{CV}$ trial among patients with diabetes and acute coronary syndromes is under way with aleglitazar (clinical-trials.gov NCT01042769).

\section{RAAS Inhibitors}

In addition to well-known actions in the vasculature, the RAAS plays an important role in skeletal muscle, liver, and adipose tissue that may interfere with insulin action and lipid control. High FFA levels and increased LDL and low HDL cholesterol levels may cause further dysregulation of the RAAS and contribute to endothelial dysfunction and atherosclerosis due to dyslipidemia and lipotoxicity. Consequently, pharmacologic treatments to block RAAS activity may benefit both vascular and metabolic physiology. Angiotensin receptor blockers and angiotensin-converting enzyme inhibitors are agents that directly affect the RAAS, either by blocking the binding of angiotensin II to the AT1 receptor or decreasing the production of angiotensin II, respectively. ${ }^{258}$ Several large-scale clinical trials have demonstrated that the use of angiotensin receptor blockers or angiotenin- 
converting enzyme inhibitors can significantly reduce the incidence of glucose intolerance, dyslipidemia, and atherosclerotic lesions in hypertensive patients and/or patients with other symptoms of the metabolic syndrome. ${ }^{259-265}$

\section{References}

1. Kim JA, Montagnani M, Koh KK, et al. Reciprocal relationships between insulin resistance and endothelial dysfunction: molecular and pathophysiological mechanisms. Circulation. 2006; 113(15): 1888-904. [PubMed: 16618833]

2. Marks JB, Raskin P. Cardiovascular risk in diabetes: a brief review. J Diabet Complications. 2000; 14(2):108-15.

3. Rubanyi GM. Endothelium-derived relaxing and contracting factors. J Cell Biochem. 1991; 46(1): 27-36. [PubMed: 1874796]

4. Aggoun Y. Obesity, metabolic syndrome, and cardiovascular disease. Pediatr Res. 2007; 61(6):6539. [PubMed: 17426660]

5. DeFronzo RA. Insulin resistance, lipotoxicity, type 2 diabetes and atherosclerosis: the missing links. The Claude Bernard lecture 2009. Diabetologia. 2010; 53(7):1270-87. [PubMed: 20361178]

6. van de Weijer T, Schrauwen-Hinderling VB, Schrauwen P. Lipotoxicity in type 2 diabetic cardiomyopathy. Cardiovasc Res. 2011; 92(1):10-8. [PubMed: 21803867]

7. Duncan JG. Lipotoxicity: what is the fate of fatty acids? J Lipid Res. 2008; 49(7):1375-6. [PubMed: 18430973]

8. Steinberg HO, Chaker H, Leaming R, et al. Obesity/ insulin resistance is associated with endothelial dysfunction. Implications for the syndrome of insulin resistance. J Clin Invest. 1996; 97(11):260110. [PubMed: 8647954]

9. Berg AH, Scherer PE. Adipose tissue, inflammation, and cardiovascular disease. Circ Res. 2005; 96(9):939-49. [PubMed: 15890981]

10. Nordestgaard BG, Benn M, Schnohr P, et al. Non-fasting triglycerides and risk of myocardial infarction, ischemic heart disease, and death in men and women. JAMA. 2007; 298(3):299-308. [PubMed: 17635890]

11. Sarwar N, Danesh J, Eiriksdottir G, et al. Triglycerides and the risk of coronary heart disease: 10,158 incident cases among 262,525 participants in 29 Western prospective studies. Circulation. 2007; 115(4):450-8. [PubMed: 17190864]

12. Abe H, Yamada N, Kamata K, et al. Hypertension, hypertriglyceridemia, and impaired endothelium-dependent vascular relaxation in mice lacking insulin receptor substrate-1. J Clin Invest. 1998; 101(8):1784-8. [PubMed: 9541510]

13. Johansen CT, Wang J, Lanktree MB, et al. Excess of rare variants in genes identified by genomewide association study of hypertriglyceridemia. Nat Genet. 2010; 42(8):684-7. [PubMed: 20657596]

14. Dallinga-Thie GM, Franssen R, Mooij HL, et al. The metabolism of triglyceride-rich lipoproteins revisited: new players, new insight. Atherosclerosis. 2010; 211(1):1-8. [PubMed: 20117784]

15. Surendran, RP.; Visser, ME.; Heemelaar, S., et al. Mutations in LPL, APOC2, APOA5, GPIHBP1 and LMF1 in patients with severe hypertriglyceridaemia. J Intern Med. 2012. http://dx.doi.org/ 10.1111/j.1365-2796.2012.02516.xEpub ahead of print

16. Young SG, Davies BS, Voss CV, et al. GPIHBP1, an endothelial cell transporter for lipoprotein lipase. J Lipid Res. 2011; 52(11):1869-84. [PubMed: 21844202]

17. van de Woestijne AP, Monajemi H, Kalkhoven E, et al. Adipose tissue dysfunction and hypertriglyceridemia: mechanisms and management. Obesity. 2011; 12(10):829-40.

18. Unger RH. Minireview: weapons of lean body mass destruction: the role of ectopic lipids in the metabolic syndrome. Endocrinology. 2003; 144(12):5159-65. [PubMed: 12960011]

19. Hokanson JE, Austin MA. Plasma triglyceride level is a risk factor for cardiovascular disease independent of high-density lipoprotein cholesterol level: a meta-analysis of population-based prospective studies. J Cardiovasc Risk. 1996; 3(2):213-9. [PubMed: 8836866]

Heart Fail Clin. Author manuscript; available in PMC 2014 August 08. 
20. Xiang GD, Xiang LW, He HL, et al. Postprandial lipaemia suppresses endothelium-dependent arterial dilation in patients with hypothyroidism. Endocrine. 2012 Feb 22. Epub ahead of print.

21. Yunoki K, Nakamura K, Miyoshi T, et al. Impact of hypertriglyceridemia on endothelial dysfunction during statin $+/-$ ezetimibe therapy in patients with coronary heart disease. Am $\mathrm{J}$ Cardiol. 2011; 108(3):333-9. [PubMed: 21545981]

22. Yunoki K, Nakamura K, Miyoshi T, et al. Ezetimibe improves postprandial hyperlipemia and its induced endothelial dysfunction. Atherosclerosis. 2011; 217(2):486-91. [PubMed: 21592480]

23. Kastelein JJ, Akdim F, Stroes ES, et al. Simvastatin with or without ezetimibe in familial hypercholesterolemia. N Engl J Med. 2008; 358(14):1431-43. [PubMed: 18376000]

24. Alipour A, van Oostrom AJ, Izraeljan A, et al. Leukocyte activation by triglyceride-rich lipoproteins. Arterioscler Thromb Vasc Biol. 2008; 28(4):792-7. [PubMed: 18218988]

25. Schwartz EA, Reaven PD. Lipolysis of triglyceride-rich lipoproteins, vascular inflammation, and atherosclerosis. Biochim Biophys Acta. 2012; 1821(5):858-66. Epub 2011 Oct 7. [PubMed: 22001233]

26. van Oostrom AJ, Sijmonsma TP, Verseyden C, et al. Postprandial recruitment of neutrophils may contribute to endothelial dysfunction. J Lipid Res. 2003; 44(3):576-83. [PubMed: 12562833]

27. Sinha R, Dufour S, Petersen KF, et al. Assessment of skeletal muscle triglyceride content by (1)H nuclear magnetic resonance spectroscopy in lean and obese adolescents: relationships to insulin sensitivity, total body fat, and central adiposity. Diabetes. 2002; 51(4):1022-7. [PubMed: 11916921]

28. Virkamaki A, Korsheninnikova E, Seppala-Lindroos A, et al. Intramyocellular lipid is associated with resistance to in vivo insulin actions on glucose uptake, antilipolysis, and early insulin signaling pathways in human skeletal muscle. Diabetes. 2001; 50(10):2337-43. [PubMed: 11574417]

29. Inoue T, Kobayashi K, Inoguchi T, et al. Reduced expression of adipose triglyceride lipase enhances tumor necrosis factor alpha-induced intercellular adhesion molecule-1 expression in human aortic endothelial cells via protein kinase C-dependent activation of nuclear factor-kappaB. J Biol Chem. 2011; 286(37):32045-53. [PubMed: 21828047]

30. Sharma S, Adrogue JV, Golfman L, et al. Intramyocardial lipid accumulation in the failing human heart resembles the lipotoxic rat heart. FASEB J. 2004; 18(14):1692-700. [PubMed: 15522914]

31. Hirano K. A novel clinical entity: triglyceride deposit cardiomyovasculopathy. J Atheroscler Thromb. 2009; 16(5):702-5. [PubMed: 19729869]

32. Bergman RN, Ader M. Free fatty acids and pathogenesis of type 2 diabetes mellitus. Trends Endocrinol Metab. 2000; 11(9):351-6. [PubMed: 11042464]

33. Kahn SE, Hull RL, Utzschneider KM. Mechanisms linking obesity to insulin resistance and type 2 diabetes. Nature. 2006; 444(7121):840-6. [PubMed: 17167471]

34. Patti ME, Butte AJ, Crunkhorn S, et al. Coordinated reduction of genes of oxidative metabolism in humans with insulin resistance and diabetes: potential role of PGC1 and NRF1. Proc Natl Acad Sci U S A. 2003; 100(14):8466-71. [PubMed: 12832613]

35. Boden G, Chen X, Ruiz J, et al. Mechanisms of fatty acid-induced inhibition of glucose uptake. J Clin Invest. 1994; 93(6):2438-46. [PubMed: 8200979]

36. Staehr P, Hother-Nielsen O, Landau BR, et al. Effects of free fatty acids per se on glucose production, gluconeogenesis, and glycogenolysis. Diabetes. 2003; 52(2):260-7. [PubMed: 12540595]

37. Kruszynska YT, Mulford MI, Yu JG, et al. Effects of nonesterified fatty acids on glucose metabolism after glucose ingestion. Diabetes. 1997; 46(10):1586-93. [PubMed: 9313754]

38. Steinberg HO, Paradisi G, Hook G, et al. Free fatty acid elevation impairs insulin-mediated vasodilation and nitric oxide production. Diabetes. 2000; 49(7):1231-8. [PubMed: 10909983]

39. Steinberg HO, Tarshoby M, Monestel R, et al. Elevated circulating free fatty acid levels impair endothelium-dependent vasodilation. J Clin Invest. 1997; 100(5):1230-9. [PubMed: 9276741]

40. Kumar S, Durrington PN, Bhatnagar D, et al. Suppression of nonesterified fatty acids to treat type A insulin resistance syndrome. Lancet. 1994; 343(8905):1073-4. [PubMed: 7909102] 
41. de Jongh RT, Serne EH, Ijzerman RG, et al. Free fatty acid levels modulate microvascular function: relevance for obesity-associated insulin resistance, hypertension, and microangiopathy. Diabetes. 2004; 53(11):2873-82. [PubMed: 15504968]

42. Pilz S, Scharnagl H, Tiran B, et al. Free fatty acids are independently associated with all-cause and cardiovascular mortality in subjects with coronary artery disease. J Clin Endocrinol Metab. 2006; 91(7):2542-7. [PubMed: 16595593]

43. Il'yasova D, Wang F, D'Agostino RB Jr, et al. Prospective association between fasting NEFA and type 2 diabetes: impact of post-load glucose. Diabetologia. 2010; 53(5):866-74. [PubMed: 20143044]

44. Byrne CD, Maison P, Halsall D, et al. Cross-sectional but not longitudinal associations between nonesterified fatty acid levels and glucose intolerance and other features of the metabolic syndrome. Diabet Med. 1999; 16(12):1007-15. [PubMed: 10656229]

45. Karpe F, Dickmann JR, Frayn KN. Fatty acids, obesity, and insulin resistance: time for a reevaluation. Diabetes. 2011; 60(10):2441-9. [PubMed: 21948998]

46. Opie LH, Walfish PG. Plasma free fatty acid concentrations in obesity. N Engl J Med. 1963; 268:757-60. [PubMed: 13940209]

47. Fielding BA, Callow J, Owen RM, et al. Postprandial lipemia: the origin of an early peak studied by specific dietary fatty acid intake during sequential meals. Am J Clin Nutr. 1996; 63(1):36-41. [PubMed: 8604667]

48. McQuaid SE, Hodson L, Neville MJ, et al. Downregulation of adipose tissue fatty acid trafficking in obesity: a driver for ectopic fat deposition? Diabetes. 2011; 60(1):47-55. [PubMed: 20943748]

49. Halcox JP, Donald AE, Ellins E, et al. Endothelial function predicts progression of carotid intimamedia thickness. Circulation. 2009; 119(7):1005-12. [PubMed: 19204308]

50. Steinberg HO, Bayazeed B, Hook G, et al. Endothelial dysfunction is associated with cholesterol levels in the high normal range in humans. Circulation. 1997; 96(10):3287-93. [PubMed: 9396418]

51. Feron O, Dessy C, Moniotte S, et al. Hypercholesterolemia decreases nitric oxide production by promoting the interaction of caveolin and endothelial nitric oxide synthase. J Clin Invest. 1999; 103(6):897-905. [PubMed: 10079111]

52. Duvillard L, Pont F, Florentin E, et al. Metabolic abnormalities of apolipoprotein B-containing lipoproteins in non-insulin-dependent diabetes: a stable isotope kinetic study. Eur J Clin Invest. 2000; 30(8):685-94. [PubMed: 10964160]

53. Verges B, Florentin E, Baillot-Rudoni S, et al. Effects of $20 \mathrm{mg}$ rosuvastatin on VLDL1-, VLDL2-, IDL- and LDL-ApoB kinetics in type 2 diabetes. Diabetologia. 2008; 51(8):1382-90. [PubMed: 18535816]

54. Koh KK, Quon MJ, Han SH, et al. Simvastatin improves flow-mediated dilation but reduces adiponectin levels and insulin sensitivity in hypercholesterolemic patients. Diabetes Care. 2008; 31(4):776-82. [PubMed: 18184901]

55. Adnitt PI, Frayn KN. Effects of metformin on glucose uptake by the isolated rat diaphragm. Br J Pharmacol. 1972; 45(1):152P-3P.

56. Blair A, Shaul PW, Yuhanna IS, et al. Oxidized low density lipoprotein displaces endothelial nitric-oxide synthase (eNOS) from plasmalemmal caveolae and impairs eNOS activation. J Biol Chem. 1999; 274(45):32512-9. [PubMed: 10542298]

57. Uittenbogaard A, Shaul PW, Yuhanna IS, et al. High density lipoprotein prevents oxidized low density lipoprotein-induced inhibition of endothelial nitric-oxide synthase localization and activation in caveolae. J Biol Chem. 2000; 275(15):11278-83. [PubMed: 10753938]

58. Kita T, Yokode M, Ishii K, et al. The role of oxidized lipoproteins in the pathogenesis of atherosclerosis. Clin Exp Pharmacol Physiol Suppl. 1992; 20:37-42. [PubMed: 1446408]

59. Maor I, Aviram M. Oxidized low density lipoprotein leads to macrophage accumulation of unesterified cholesterol as a result of lysosomal trapping of the lipoprotein hydrolyzed cholesteryl ester. J Lipid Res. 1994; 35(5):803-19. [PubMed: 8071603]

60. Verges B, Brun JM, Vaillant G, et al. Influence of obesity and hypertriglyceridaemia on the low HDL2-cholesterol level and on its relationship with prevalence of atherosclerosis in type 2 diabetes. Diabete Metab. 1992; 18(4):289-97. [PubMed: 1459317] 
61. Golay A, Zech L, Shi MZ, et al. High density lipoprotein (HDL) metabolism in noninsulindependent diabetes mellitus: measurement of HDL turnover using tritiated HDL. J Clin Endocrinol Metab. 1987; 65(3):512-8. [PubMed: 3114304]

62. Duvillard L, Pont F, Florentin E, et al. Inefficiency of insulin therapy to correct apolipoprotein A-I metabolic abnormalities in non-insulin-dependent diabetes mellitus. Atherosclerosis. 2000; 152(1): 229-37. [PubMed: 10996359]

63. Besler C, Heinrich K, Rohrer L, et al. Mechanisms underlying adverse effects of HDL on eNOSactivating pathways in patients with coronary artery disease. J Clin Invest. 2011; 121(7):2693708. [PubMed: 21701070]

64. Persegol L, Verges B, Foissac M, et al. Inability of HDL from type 2 diabetic patients to counteract the inhibitory effect of oxidised LDL on endothelium-dependent vasorelaxation. Diabetologia. 2006; 49(6):1380-6. [PubMed: 16596357]

65. Abel ED, Litwin SE, Sweeney G. Cardiac remodeling in obesity. Physiol Rev. 2008; 88(2):389419. [PubMed: 18391168]

66. Lopaschuk GD, Folmes CD, Stanley WC. Cardiac energy metabolism in obesity. Circ Res. 2007; 101(4):335-47. [PubMed: 17702980]

67. Hall JE, da Silva AA, do Carmo JM, et al. Obesity-induced hypertension: role of sympathetic nervous system, leptin, and melanocortins. J Biol Chem. 2010; 285(23):17271-6. [PubMed: 20348094]

68. Kenchaiah S, Evans JC, Levy D, et al. Obesity and the risk of heart failure. N Engl J Med. 2002; 347(5):305-13. [PubMed: 12151467]

69. Dyntar D, Eppenberger-Eberhardt M, Maedler K, et al. Glucose and palmitic acid induce degeneration of myofibrils and modulate apoptosis in rat adult cardiomyocytes. Diabetes. 2001; 50(9):2105-13. [PubMed: 11522678]

70. Park TS, Hu Y, Noh HL, et al. Ceramide is a cardio-toxin in lipotoxic cardiomyopathy. J Lipid Res. 2008; 49(10):2101-12. [PubMed: 18515784]

71. Chess DJ, Lei B, Hoit BD, et al. Effects of a high saturated fat diet on cardiac hypertrophy and dysfunction in response to pressure overload. J Diabet Complications. 2008; 14(1):82-8.

72. Galvao TF, Brown BH, Hecker PA, et al. High intake of saturated fat, but not polyunsaturated fat, improves survival in heart failure despite persistent mitochondrial defects. Cardiovasc Res. 2012; 93(1):24-32. [PubMed: 21960686]

73. Okere IC, Chandler MP, McElfresh TA, et al. Differential effects of saturated and unsaturated fatty acid diets on cardiomyocyte apoptosis, adipose distribution, and serum leptin. Am J Physiol Heart Circ Physiol. 2006; 291(1):H38-44. [PubMed: 16443671]

74. Okere IC, Chess DJ, McElfresh TA, et al. High-fat diet prevents cardiac hypertrophy and improves contractile function in the hypertensive dahl salt-sensitive rat. Clin Exp Pharmacol Physiol. 2005; 32(10):825-31. [PubMed: 16173943]

75. Stanley WC, Dabkowski ER, Ribeiro RF Jr, et al. Dietary fat and heart failure: moving from lipotoxicity to lipoprotection. Circ Res. 2012; 110(5):764-76. [PubMed: 22383711]

76. Halton TL, Willett WC, Liu S, et al. Low-carbohydrate-diet score and the risk of coronary heart disease in women. N Engl J Med. 2006; 355(19):1991-2002. [PubMed: 17093250]

77. Hu FB, Willett WC. Optimal diets for prevention of coronary heart disease. JAMA. 2002; 288(20): 2569-78. [PubMed: 12444864]

78. Lavie CJ, Milani RV, Mehra MR, et al. Omega-3 polyunsaturated fatty acids and cardiovascular diseases. J Am Coll Cardiol. 2009; 54(7):585-94. [PubMed: 19660687]

79. Mozaffarian D, Wu JH. Omega-3 fatty acids and cardiovascular disease: effects on risk factors, molecular pathways, and clinical events. J Am Coll Cardiol. 2011; 58(20):2047-67. [PubMed: 22051327]

80. Foley R. Cardiac disease in diabetic patients with renal disease. Acta Diabetol. 2002; 39(Suppl 1):S9-14. [PubMed: 12038700]

81. Mogensen CE, Christensen CK, Vittinghus E. The stages in diabetic renal disease. With emphasis on the stage of incipient diabetic nephropathy. Diabetes. 1983; 32(Suppl 2):64-78. [PubMed: 6400670] 
82. Stam F, van Guldener C, Becker A, et al. Endothelial dysfunction contributes to renal functionassociated cardiovascular mortality in a population with mild renal insufficiency: the Hoorn study. J Am Soc Nephrol. 2006; 17(2):537-45. [PubMed: 16382015]

83. Stehouwer CD. Endothelial dysfunction in diabetic nephropathy: state of the art and potential significance for non-diabetic renal disease. Nephrol Dial Transplant. 2004; 19(4):778-81. [PubMed: 15031329]

84. Attia DM, Ni ZN, Boer P, et al. Proteinuria is preceded by decreased nitric oxide synthesis and prevented by a NO donor in cholesterol-fed rats. Kidney Int. 2002; 61(5):1776-87. [PubMed: 11967027]

85. Vaziri ND, Moradi H. Mechanisms of dyslipidemia of chronic renal failure. Hemodial Int. 2006; 10(1):1-7. [PubMed: 16441821]

86. Vaziri ND. Dyslipidemia of chronic renal failure: the nature, mechanisms, and potential consequences. Am J Physiol Renal Physiol. 2006; 290(2):F262-72. [PubMed: 16403839]

87. Kronenberg F, Kuen E, Ritz E, et al. Lipoprotein(a) serum concentrations and apolipoprotein(a) phenotypes in mild and moderate renal failure. J Am Soc Nephrol. 2000; 11(1):105-15. [PubMed: 10616846]

88. Prinsen BH, de Sain-van der Velden MG, de Koning EJ, et al. Hypertriglyceridemia in patients with chronic renal failure: possible mechanisms. Kidney Int Suppl. 2003; (84):S121-4. [PubMed: 12694325]

89. Dalrymple LS, Kaysen GA. The effect of lipoproteins on the development and progression of renal disease. Am J Nephrol. 2008; 28(5):723-31. [PubMed: 18434711]

90. Baines RJ, Brunskill NJ. Tubular toxicity of proteinuria. Nat Rev Nephrol. 2011; 7(3):177-80. [PubMed: 21151210]

91. Iacobini C, Menini S, Ricci C, et al. Advanced lipoxidation end-products mediate lipid-induced glomerular injury: role of receptor-mediated mechanisms. J Pathol. 2009; 218(3):360-9. [PubMed: 19334049]

92. Nosadini R, Tonolo G. Role of oxidized low density lipoproteins and free fatty acids in the pathogenesis of glomerulopathy and tubulointerstitial lesions in type 2 diabetes. Nutr Metab Cardiovasc Dis. 2011; 21(2):79-85. [PubMed: 21186102]

93. Obrosova IG. Diabetic painful and insensate neuropathy: pathogenesis and potential treatments. Neurotherapeutics. 2009; 6(4):638-47. [PubMed: 19789069]

94. Andersen H. Motor dysfunction in diabetes. Diabetes Metab Res Rev. 2012; 28(Suppl 1):89-92. [PubMed: 22271730]

95. Said G, Baudoin D, Toyooka K. Sensory loss, pains, motor deficit and axonal regeneration in length-dependent diabetic polyneuropathy. J Neurol. 2008; 255(11):1693-702. [PubMed: 18825430]

96. Cameron NE, Cotter MA. Diabetes causes an early reduction in autonomic ganglion blood flow in rats. J Diabet Complications. 2001; 15(4):198-202.

97. Zent R, Pozzi A. Angiogenesis in diabetic nephropathy. Semin Nephrol. 2007; 27(2):161-71. [PubMed: 17418685]

98. Tesfaye S, Chaturvedi N, Eaton SE, et al. Vascular risk factors and diabetic neuropathy. N Engl J Med. 2005; 352(4):341-50. [PubMed: 15673800]

99. Witte DR, Tesfaye S, Chaturvedi N, et al. Risk factors for cardiac autonomic neuropathy in type 1 diabetes mellitus. Diabetologia. 2005; 48(1):164-71. [PubMed: 15619072]

100. Lacigova S, Bartunek L, Cechurova D, et al. Influence of cardiovascular autonomic neuropathy on atherogenesis and heart function in patients with type 1 diabetes. Diabetes Res Clin Pract. 2009; 83(1):26-31. [PubMed: 19013660]

101. Obrosova IG, Ilnytska O, Lyzogubov VV, et al. High-fat diet induced neuropathy of pre-diabetes and obesity: effects of "healthy" diet and aldose reductase inhibition. Diabetes. 2007; 56(10): 2598-608. [PubMed: 17626889]

102. Padilla A, Descorbeth M, Almeyda AL, et al. Hyperglycemia magnifies Schwann cell dysfunction and cell death triggered by PA-induced lipotoxicity. Brain Res. 2011; 1370:64-79. [PubMed: 21108938] 
103. Nowicki M, Muller K, Serke H, et al. Oxidized low-density lipoprotein (oxLDL)-induced cell death in dorsal root ganglion cell cultures depends not on the lectin-like oxLDL receptor-1 but on the toll-like receptor-4. J Neurosci Res. 2010; 88(2):403-12. [PubMed: 19705455]

104. Yan SS, Chen D, Yan S, et al. RAGE is a key cellular target for Abeta-induced perturbation in Alzheimer's disease. Front Biosci. 2012; 4:240-50.

105. Johannsen DL, Ravussin E. Can increased muscle ROS scavenging keep older animals young and metabolically fit? Cell Metab. 2010; 12(6):557-8. [PubMed: 21109187]

106. Preedy VR, Adachi J, Asano M, et al. Free radicals in alcoholic myopathy: indices of damage and preventive studies. Free Radic Biol Med. 2002; 32(8):683-7. [PubMed: 11937294]

107. Victor VM, Rocha M, Herance R, et al. Oxidative stress and mitochondrial dysfunction in type 2 diabetes. Curr Pharm Des. 2011; 17(36):3947-58. [PubMed: 22188447]

108. Hayek T, Kaplan M, Kerry R, et al. Macrophage NADPH oxidase activation, impaired cholesterol fluxes, and increased cholesterol biosynthesis in diabetic mice: a stimulatory role for D-glucose. Atherosclerosis. 2007; 195(2):277-86. [PubMed: 17258748]

109. Maloney E, Sweet IR, Hockenbery DM, et al. Activation of NF-kappaB by palmitate in endothelial cells: a key role for NADPH oxidase-derived super-oxide in response to TLR4 activation. Arterioscler Thromb Vasc Biol. 2009; 29(9):1370-5. [PubMed: 19542021]

110. Steinbeck MJ, Robinson JM, Karnovsky MJ. Activation of the neutrophil NADPH-oxidase by free fatty acids requires the ionized carboxyl group and partitioning into membrane lipid. J Leukoc Biol. 1991; 49(4):360-8. [PubMed: 1848271]

111. Chinen I, Shimabukuro M, Yamakawa K, et al. Vascular lipotoxicity: endothelial dysfunction via fatty-acid-induced reactive oxygen species overproduction in obese Zucker diabetic fatty rats. Endocrinology. 2007; 148(1):160-5. [PubMed: 17023526]

112. Curnutte JT, Erickson RW, Ding J, et al. Reciprocal interactions between protein kinase $C$ and components of the NADPH oxidase complex may regulate superoxide production by neutrophils stimulated with a phorbol ester. J Biol Chem. 1994; 269(14):10813-9. [PubMed: 8144669]

113. Nauseef WM, Volpp BD, McCormick S, et al. Assembly of the neutrophil respiratory burst oxidase. Protein kinase $\mathrm{C}$ promotes cytoskeletal and membrane association of cytosolic oxidase components. J Biol Chem. 1991; 266(9):5911-7. [PubMed: 1848559]

114. Hulsmans M, Van Dooren E, Holvoet P. Mitochondrial reactive oxygen species and risk of atherosclerosis. Curr Atheroscler Rep. 2012; 14(3):264-76. [PubMed: 22350585]

115. Schonfeld P, Wojtczak L. Fatty acids as modulators of the cellular production of reactive oxygen species. Free Radic Biol Med. 2008; 45(3):231-41. [PubMed: 18482593]

116. Rocha M, Apostolova N, Hernandez-Mijares A, et al. Oxidative stress and endothelial dysfunction in cardiovascular disease: mitochondria-targeted therapeutics. Curr Med Chem. 2010; 17(32):3827-41. [PubMed: 20858217]

117. Kim JA, Wei Y, Sowers JR. Role of mitochondrial dysfunction in insulin resistance. Circ Res. 2008; 102(4):401-14. [PubMed: 18309108]

118. Moukdar F, Robidoux J, Lyght O, et al. Reduced antioxidant capacity and diet-induced atherosclerosis in uncoupling protein-2-deficient mice. J Lipid Res. 2009; 50(1):59-70. [PubMed: 18698091]

119. Erdei N, Toth A, Pasztor ET, et al. High-fat diet-induced reduction in nitric oxide-dependent arteriolar dilation in rats: role of xanthine oxidase-derived superoxide anion. Am J Physiol Heart Circ Physiol. 2006; 291(5):H2107-15. [PubMed: 16798827]

120. Pannirselvam M, Verma S, Anderson TJ, et al. Cellular basis of endothelial dysfunction in small mesenteric arteries from spontaneously diabetic $(\mathrm{db} / \mathrm{db}-/-)$ mice: role of decreased tetrahydrobiopterin bioavailability. Br J Pharmacol. 2002; 136(2):255-63. [PubMed: 12010774]

121. Vasquez-Vivar J, Kalyanaraman B, Martasek P. The role of tetrahydrobiopterin in superoxide generation from eNOS: enzymology and physiological implications. Free Radic Res. 2003; 37(2):121-7. [PubMed: 12653200]

122. Wellen KE, Hotamisligil GS. Obesity-induced inflammatory changes in adipose tissue. J Clin Invest. 2003; 112(12):1785-8. [PubMed: 14679172] 
123. Xu H, Barnes GT, Yang Q, et al. Chronic inflammation in fat plays a crucial role in the development of obesity-related insulin resistance. J Clin Invest. 2003; 112(12):1821-30. [PubMed: 14679177]

124. Linton MF, Fazio S. Macrophages, inflammation, and atherosclerosis. Int J Obes Relat Metab Disord. 2003; 27(Suppl 3):S35-40. [PubMed: 14704742]

125. Kim F, Pham M, Luttrell I, et al. Toll-like receptor-4 mediates vascular inflammation and insulin resistance in diet-induced obesity. Circ Res. 2007; 100(11):1589-96. [PubMed: 17478729]

126. Shi H, Kokoeva MV, Inouye K, et al. TLR4 links innate immunity and fatty acid-induced insulin resistance. J Clin Invest. 2006; 116(11):3015-25. [PubMed: 17053832]

127. Nguyen MT, Favelyukis S, Nguyen AK, et al. A subpopulation of macrophages infiltrates hypertrophic adipose tissue and is activated by free fatty acids via toll-like receptors 2 and 4 and JNK-dependent pathways. J Biol Chem. 2007; 282(48):35279-92. [PubMed: 17916553]

128. Michelsen KS, Doherty TM, Shah PK, et al. Role of Toll-like receptors in atherosclerosis. Circ Res. 2004; 95(12):e96-7. [PubMed: 15591233]

129. Son JW, Jang EH, Kim MK, et al. Serum BMP-4 levels in relation to arterial stiffness and carotid atherosclerosis in patients with Type 2 diabetes. Biomark Med. 2011; 5(6):827-35. [PubMed: 22103619]

130. Geng H, Wang A, Rong G, et al. The effects of ox-LDL in human atherosclerosis may be mediated in part via the toll-like receptor 4 pathway. Mol Cell Biochem. 2010; 342(1-2):201-6. [PubMed: 20467793]

131. Holland WL, Bikman BT, Wang LP, et al. Lipid-induced insulin resistance mediated by the proinflammatory receptor TLR4 requires saturated fatty acid-induced ceramide biosynthesis in mice. J Clin Invest. 2011; 121(5):1858-70. [PubMed: 21490391]

132. Montagnani M, Chen H, Barr VA, et al. Insulin-stimulated activation of eNOS is independent of $\mathrm{Ca} 2+$ but requires phosphorylation by Akt at Ser(1179). J Biol Chem. 2001; 276(32):30392-8. [PubMed: 11402048]

133. Montagnani M, Ravichandran LV, Chen H, et al. Insulin receptor substrate-1 and phosphoinositide-dependent kinase- 1 are required for insulin-stimulated production of nitric oxide in endothelial cells. Mol Endocrinol. 2002; 16(8):1931-42. [PubMed: 12145346]

134. Gao Z, Hwang D, Bataille F, et al. Serine phosphorylation of insulin receptor substrate 1 by inhibitor kappa B kinase complex. J Biol Chem. 2002; 277(50):48115-21. [PubMed: 12351658]

135. Lee S, Lynn EG, Kim JA, et al. Protein kinase C-zeta phosphorylates insulin receptor substrate-1, -3 , and -4 but not -2 : isoform specific determinants of specificity in insulin signaling. Endocrinology. 2008; 149(5):2451-8. [PubMed: 18202124]

136. Steinberg HO, Brechtel G, Johnson A, et al. Insulin-mediated skeletal muscle vasodilation is nitric oxide dependent. A novel action of insulin to increase nitric oxide release. J Clin Invest. 1994; 94(3):1172-9. [PubMed: 8083357]

137. Bikman BT, Summers SA. Ceramides as modulators of cellular and whole-body metabolism. J Clin Invest. 2011; 121(11):4222-30. [PubMed: 22045572]

138. Wilson-Fritch L, Burkart A, Bell G, et al. Mitochondrial biogenesis and remodeling during adipogenesis and in response to the insulin sensitizer rosiglitazone. Mol Cell Biol. 2003; 23(3): 1085-94. [PubMed: 12529412]

139. Bogacka I, Xie H, Bray GA, et al. Pioglitazone induces mitochondrial biogenesis in human subcutaneous adipose tissue in vivo. Diabetes. 2005; 54(5):1392-9. [PubMed: 15855325]

140. Nisoli E, Clementi E, Carruba MO, et al. Defective mitochondrial biogenesis: a hallmark of the high cardiovascular risk in the metabolic syndrome? Circ Res. 2007; 100(6):795-806. [PubMed: 17395885]

141. Le Gouill E, Jimenez M, Binnert C, et al. Endothelial nitric oxide synthase (eNOS) knockout mice have defective mitochondrial beta-oxidation. Diabetes. 2007; 56(11):2690-6. [PubMed: 17682093]

142. Petersen KF, Dufour S, Befroy D, et al. Impaired mitochondrial activity in the insulin-resistant offspring of patients with type 2 diabetes. N Engl J Med. 2004; 350(7):664-71. [PubMed: 14960743] 
143. Ozcan U, Cao Q, Yilmaz E, et al. Endoplasmic reticulum stress links obesity, insulin action, and type 2 diabetes. Science. 2004; 306(5695):457-61. [PubMed: 15486293]

144. Ozcan U, Yilmaz E, Ozcan L, et al. Chemical chaperones reduce ER stress and restore glucose homeostasis in a mouse model of type 2 diabetes. Science. 2006; 313(5790):1137-40. [PubMed: 16931765]

145. Boden G, Duan X, Homko C, et al. Increase in endoplasmic reticulum stress-related proteins and genes in adipose tissue of obese, insulin-resistant individuals. Diabetes. 2008; 57(9):2438-44. [PubMed: 18567819]

146. Kars M, Yang L, Gregor MF, et al. Tauroursodeoxycholic acid may improve liver and muscle but not adipose tissue insulin sensitivity in obese men and women. Diabetes. 2010; 59(8):1899-905. [PubMed: 20522594]

147. Hotamisligil GS. Inflammation and endoplasmic reticulum stress in obesity and diabetes. Int $\mathbf{J}$ Obes (Lond). 2008; 32(Suppl 7):S52-4. [PubMed: 19136991]

148. Vladykovskaya E, Sithu SD, Haberzettl P, et al. The lipid peroxidation product, 4-hydroxytrans-2-none-nal causes endothelial activation by inducing endoplasmic reticulum stress. J Biol Chem. 2012 Jan 6. Epub ahead of print.

149. Zhang Y, Xue R, Zhang Z, et al. Palmitic and linoleic acids induce ER stress and apoptosis in hepatoma cells. Lipids Health Dis. 2012; 11:1. [PubMed: 22221411]

150. Fu S, Yang L, Li P, et al. Aberrant lipid metabolism disrupts calcium homeostasis causing liver endoplasmic reticulum stress in obesity. Nature. 2011; 473(7348):528-31. [PubMed: 21532591]

151. Tabas I. The role of endoplasmic reticulum stress in the progression of atherosclerosis. Circ Res. 2010; 107(7):839-50. [PubMed: 20884885]

152. Ji C, Kaplowitz N. ER stress: can the liver cope? J Hepatol. 2006; 45(2):321-33. [PubMed: 16797772]

153. Gregor MF, Yang L, Fabbrini E, et al. Endoplasmic reticulum stress is reduced in tissues of obese subjects after weight loss. Diabetes. 2009; 58(3):693-700. [PubMed: 19066313]

154. Aguirre V, Uchida T, Yenush L, et al. The c-Jun NH(2)-terminal kinase promotes insulin resistance during association with insulin receptor substrate-1 and phosphorylation of Ser(307). J Biol Chem. 2000; 275(12):9047-54. [PubMed: 10722755]

155. Carlson CJ, White MF, Rondinone CM. Mammalian target of rapamycin regulates IRS-1 serine 307 phosphorylation. Biochem Biophys Res Commun. 2004; 316(2):533-9. [PubMed: 15020250]

156. Hilder TL, Tou JC, Grindeland RE, et al. Phosphorylation of insulin receptor substrate-1 serine 307 correlates with JNK activity in atrophic skeletal muscle. FEBS Lett. 2003; 553(1-2):63-7. [PubMed: 14550547]

157. Chun L, Junlin Z, Aimin W, et al. Inhibition of ceramide synthesis reverses endothelial dysfunction and atherosclerosis in streptozotocin-induced diabetic rats. Diabetes Res Clin Pract. 2011; 93(1):77-85. [PubMed: 21492950]

158. Datta SR, Dudek H, Tao X, et al. Akt phosphorylation of BAD couples survival signals to the cell-intrinsic death machinery. Cell. 1997; 91(2):231-41. [PubMed: 9346240]

159. Zhou H, Summers SA, Birnbaum MJ, et al. Inhibition of Akt kinase by cell-permeable ceramide and its implications for ceramide-induced apoptosis. J Biol Chem. 1998; 273(26):16568-75. [PubMed: 9632728]

160. Katsuyama K, Shichiri M, Marumo F, et al. Role of nuclear factor-kappaB activation in cytokineand sphingomyelinase-stimulated inducible nitric oxide synthase gene expression in vascular smooth muscle cells. Endocrinology. 1998; 139(11):4506-12. [PubMed: 9794459]

161. Pahan K, Sheikh FG, Khan M, et al. Sphingomyelinase and ceramide stimulate the expression of inducible nitric-oxide synthase in rat primary astro-cytes. J Biol Chem. 1998; 273(5):2591-600. [PubMed: 9446561]

162. Dimmeler S, Haendeler J, Galle J, et al. Oxidized low-density lipoprotein induces apoptosis of human endothelial cells by activation of CPP32-like proteases. A mechanistic clue to the 'response to injury' hypothesis. Circulation. 1997; 95(7):1760-3. [PubMed: 9107159] 
163. Suc I, Escargueil-Blanc I, Troly M, et al. HDL and ApoA prevent cell death of endothelial cells induced by oxidized LDL. Arterioscler Thromb Vasc Biol. 1997; 17(10):2158-66. [PubMed: 9351385]

164. Noor R, Shuaib U, Wang CX, et al. High-density lipoprotein cholesterol regulates endothelial progenitor cells by increasing eNOS and preventing apoptosis. Atherosclerosis. 2007; 192(1):929. [PubMed: 16884727]

165. Hoffmann J, Haendeler J, Aicher A, et al. Aging enhances the sensitivity of endothelial cells toward apoptotic stimuli: important role of nitric oxide. Circ Res. 2001; 89(8):709-15. [PubMed: 11597994]

166. Barlow CE, LaMonte MJ, Fitzgerald SJ, et al. Cardiorespiratory fitness is an independent predictor of hypertension incidence among initially normotensive healthy women. Am J Epidemiol. 2006; 163(2):142-50. [PubMed: 16293717]

167. Sui X, LaMonte MJ, Laditka JN, et al. Cardiorespiratory fitness and adiposity as mortality predictors in older adults. JAMA. 2007; 298(21):2507-16. [PubMed: 18056904]

168. Carter SL, Rennie C, Tarnopolsky MA. Substrate utilization during endurance exercise in men and women after endurance training. Am J Physiol Endocrinol Metab. 2001; 280(6):E898-907. [PubMed: 11350771]

169. Schrauwen P, van Aggel-Leijssen DP, Hul G, et al. The effect of a 3-month low-intensity endurance training program on fat oxidation and acetyl-CoA carboxylase-2 expression. Diabetes. 2002; 51(7):2220-6. [PubMed: 12086953]

170. Liu L, Shi X, Bharadwaj KG, et al. DGAT1 expression increases heart triglyceride content but ameliorates lipotoxicity. J Biol Chem. 2009; 284(52):36312-23. [PubMed: 19778901]

171. Criswell D, Powers S, Dodd S, et al. High intensity training-induced changes in skeletal muscle anti-oxidant enzyme activity. Med Sci Sports Exerc. 1993; 25(10):1135-40. [PubMed: 8231758]

172. Pinto A, Di Raimondo D, Tuttolomondo A, et al. Effects of physical exercise on inflammatory markers of atherosclerosis. Curr Pharm Des. 2012; 287(14):11398-409.

173. Menshikova EV, Ritov VB, Ferrell RE, et al. Characteristics of skeletal muscle mitochondrial biogenesis induced by moderate-intensity exercise and weight loss in obesity. J Appl Phys. 2007; 103(1):21-7.

174. Richter EA, Ruderman NB. AMPK and the biochemistry of exercise: implications for human health and disease. Biochem J. 2009; 418(2):261-75. [PubMed: 19196246]

175. Ropelle ER, Flores MB, Cintra DE, et al. IL-6 and IL-10 anti-inflammatory activity links exercise to hypothalamic insulin and leptin sensitivity through IKKbeta and ER stress inhibition. PLoS Biol. 2010; 8(8):e1000465. [PubMed: 20808781]

176. Christ-Roberts CY, Pratipanawatr T, Pratipanawatr W, et al. Exercise training increases glycogen synthase activity and GLUT4 expression but not insulin signaling in overweight nondiabetic and type 2 diabetic subjects. Metabolism. 2004; 53(9):1233-42. [PubMed: 15334390]

177. Maiorana A, O’Driscoll G, Taylor R, et al. Exercise and the nitric oxide vasodilator system. Sports Med. 2003; 33(14):1013-35. [PubMed: 14599231]

178. Colberg SR, Albright AL, Blissmer BJ, et al. Exercise and Type 2 Diabetes. Med Sci Sports Exerc. 2010 Dec; 42(12):2283-303.

179. Lim S, Despres JP, Koh KK. Prevention of atherosclerosis in overweight/obese patients. - In need of novel multi-targeted approaches. Circ J. 2011; 75(5):1019-27. [PubMed: 21441697]

180. Istvan ES, Deisenhofer J. Structural mechanism for statin inhibition of HMG-CoA reductase. Science. 2001; 292(5519):1160-4. [PubMed: 11349148]

181. Group HPSC. MRC/BHF Heart Protection Study of cholesterol lowering with simvastatin in 20,536 high-risk individuals: a randomised placebo-controlled trial. Lancet. 2002; 360(9326):722. [PubMed: 12114036]

182. Ridker PM, Cannon CP, Morrow D, et al. C-reactive protein levels and outcomes after statin therapy. N Engl J Med. 2005; 352(1):20-8. [PubMed: 15635109]

183. Ridker PM, Danielson E, Fonseca FA, et al. Reduction in C-reactive protein and LDL cholesterol and cardiovascular event rates after initiation of rosuvastatin: a prospective study of the JUPITER trial. Lancet. 2009; 373(9670):1175-82. [PubMed: 19329177] 
184. Sorrentino S, Landmesser U. Nonlipid-lowering effects of statins. Curr Treat Options Cardiovasc Med. 2005; 7(6):459-66. [PubMed: 16283973]

185. Zhou Q, Liao JK. Pleiotropic effects of statins. - Basic research and clinical perspectives. Circ J. 2010; 74(5):818-26. [PubMed: 20424337]

186. Wang CY, Liu PY, Liao JK. Pleiotropic effects of statin therapy: molecular mechanisms and clinical results. Trends Mol Med. 2008; 14(1):37-44. [PubMed: 18068482]

187. Colhoun HM, Betteridge DJ, Durrington PN, et al. Primary prevention of cardiovascular disease with atorvastatin in type 2 diabetes in the Collaborative Atorvastatin Diabetes Study (CARDS): multicentre randomised placebo-controlled trial. Lancet. 2004; 364(9435):685-96. [PubMed: 15325833]

188. Koh KK, Quon MJ, Rosenson RS, et al. Vascular and metabolic effects of treatment of combined hyperlipidemia: focus on statins and fibrates. Int J Cardiol. 2008; 124(2):149-59. [PubMed: 17658632]

189. Rawlings R, Nohria A, Liu PY, et al. Comparison of effects of rosuvastatin (10 mg) versus atorvastatin $(40 \mathrm{mg})$ on rho kinase activity in caucasian men with a previous atherosclerotic event. Am J Cardiol. 2009; 103(4):437-41. [PubMed: 19195498]

190. Liu PY, Liu YW, Lin LJ, et al. Evidence for statin pleiotropy in humans: differential effects of statins and ezetimibe on rho-associated coiled-coil containing protein kinase activity, endothelial function, and inflammation. Circulation. 2009; 119(1):131-8. [PubMed: 19075102]

191. Gabay C, Kushner I. Acute-phase proteins and other systemic responses to inflammation. N Engl J Med. 1999; 340(6):448-54. [PubMed: 9971870]

192. Wang CH, Li SH, Weisel RD, et al. C-reactive protein upregulates angiotensin type 1 receptors in vascular smooth muscle. Circulation. 2003; 107(13):1783-90. [PubMed: 12665485]

193. Kleemann R, Verschuren L, de Rooij BJ, et al. Evidence for anti-inflammatory activity of statins and PPARalpha activators in human C-reactive protein transgenic mice in vivo and in cultured human hepatocytes in vitro. Blood. 2004; 103(11):4188-94. [PubMed: 14976045]

194. Laufs U, La Fata V, Plutzky J, et al. Upregulation of endothelial nitric oxide synthase by HMG CoA reductase inhibitors. Circulation. 1998; 97(12):1129-35. [PubMed: 9537338]

195. Laufs U, Liao JK. Post-transcriptional regulation of endothelial nitric oxide synthase mRNA stability by Rho GTPase. J Biol Chem. 1998; 273(37):24266-71. [PubMed: 9727051]

196. Kosmidou I, Moore JP, Weber M, et al. Statin treatment and $3^{\prime}$ polyadenylation of eNOS mRNA. Arterioscler Thromb Vasc Biol. 2007; 27(12):2642-9. [PubMed: 17916773]

197. Wenzel P, Daiber A, Oelze M, et al. Mechanisms underlying recoupling of eNOS by HMG-CoA reductase inhibition in a rat model of streptozotocin-induced diabetes mellitus. Atherosclerosis. 2008; 198(1):65-76. [PubMed: 18061195]

198. Antoniades C, Bakogiannis C, Leeson P, et al. Rapid, direct effects of statin treatment on arterial redox state and nitric oxide bioavailability in human atherosclerosis via tetrahydrobiopterinmediated endothelial nitric oxide synthase coupling. Circulation. 2011; 124(3):335-45. [PubMed: 21730307]

199. Hattori Y, Nakanishi N, Akimoto K, et al. HMG-CoA reductase inhibitor increases GTP cyclohydrolase I mRNA and tetrahydrobiopterin in vascular endothelial cells. Arterioscler Thromb Vasc Biol. 2003; 23(2):176-82. [PubMed: 12588756]

200. Rueckschloss U, Galle J, Holtz J, et al. Induction of NAD(P)H oxidase by oxidized low-density lipoprotein in human endothelial cells: antioxidative potential of hydroxymethylglutaryl coenzyme A reductase inhibitor therapy. Circulation. 2001; 104(15):1767-72. [PubMed: 11591612]

201. Mason RP, Kubant R, Heeba G, et al. Synergistic effect of amlodipine and atorvastatin in reversing LDL-induced endothelial dysfunction. Pharm Res. 2008; 25(8):1798-806. [PubMed: 18087679]

202. Otto A, Fontaine J, Tschirhart E, et al. Rosuvastatin treatment protects against nitrate-induced oxidative stress in eNOS knockout mice: implication of the NAD $(\mathrm{P}) \mathrm{H}$ oxidase pathway. $\mathrm{Br} \mathrm{J}$ Pharmacol. 2006; 148(4):544-52. [PubMed: 16633368] 
203. Cangemi R, Loffredo L, Carnevale R, et al. Early decrease of oxidative stress by atorvastatin in hypercholesterolaemic patients: effect on circulating vitamin E. Eur Heart J. 2008; 29(1):54-62. [PubMed: 18065424]

204. Morawietz H, Erbs S, Holtz J, et al. Endothelial protection, AT1 blockade and cholesteroldependent oxidative stress: the EPAS trial. Circulation. 2006; 114(Suppl 1):I296-301. [PubMed: 16820589]

205. Nickenig G, Baumer AT, Temur Y, et al. Statin-sensitive dysregulated AT1 receptor function and density in hypercholesterolemic men. Circulation. 1999; 100(21):2131-4. [PubMed: 10571970]

206. Plutzky J. The PPAR-RXR transcriptional complex in the vasculature: energy in the balance. Circ Res. 2011; 108(8):1002-16. [PubMed: 21493923]

207. Yki-Jarvinen H. Thiazolidinediones. N Engl J Med. 2004; 351(11):1106-18. [PubMed: 15356308]

208. Friedland SN, Leong A, Filion KB, et al. The cardiovascular effects of peroxisome proliferatoractivated receptor agonists. Am J Med. 2012; 125(2):126-33. [PubMed: 22269613]

209. Willson TM, Brown PJ, Sternbach DD, et al. The PPARs: from orphan receptors to drug discovery. J Med Chem. 2000; 43(4):527-50. [PubMed: 10691680]

210. Marx N, Sukhova GK, Collins T, et al. PPARalpha activators inhibit cytokine-induced vascular cell adhesion molecule-1 expression in human endothelial cells. Circulation. 1999; 99(24):312531. [PubMed: 10377075]

211. Ziouzenkova O, Perrey S, Asatryan L, et al. Lipolysis of triglyceride-rich lipoproteins generates PPAR ligands: evidence for an antiinflammatory role for lipoprotein lipase. Acad Sci U S A. 2003; 100(5):2730-5.

212. Marx N, Mackman N, Schonbeck U, et al. PPARalpha activators inhibit tissue factor expression and activity in human monocytes. Circulation. 2001; 103(2):213-9. [PubMed: 11208679]

213. Muhlestein JB, May HT, Jensen JR, et al. The reduction of inflammatory biomarkers by statin, fibrate, and combination therapy among diabetic patients with mixed dyslipidemia: the DIACOR (Diabetes and Combined Lipid Therapy Regimen) study. J Am Coll Cardiol. 2006; 48(2):396401. [PubMed: 16843192]

214. Rigamonti E, Chinetti-Gbaguidi G, Staels B. Regulation of macrophage functions by PPARalpha, PPAR-gamma, and LXRs in mice and men. Arterioscler Thromb Vasc Biol. 2008; 28(6): 1050-9. [PubMed: 18323516]

215. Babaev VR, Ishiguro H, Ding L, et al. Macrophage expression of peroxisome proliferatoractivated receptor-alpha reduces atherosclerosis in low-density lipoprotein receptor-deficient mice. Circulation. 2007; 116(12):1404-12. [PubMed: 17724261]

216. Diep QN, Amiri F, Touyz RM, et al. PPARalpha activator effects on Ang II-induced vascular oxidative stress and inflammation. Hypertension. 2002; 40(6):866-71. [PubMed: 12468571]

217. Koh KK, Han SH, Quon MJ, et al. Beneficial effects of fenofibrate to improve endothelial dysfunction and raise adiponectin levels in patients with primary hypertriglyceridemia. Diabetes Care. 2005; 28(6):1419-24. [PubMed: 15920062]

218. Rubins HB, Robins SJ, Collins D, et al. Veterans Affairs High-Density Lipoprotein Cholesterol Intervention Trial Study Group. Gemfibrozil for the secondary prevention of coronary heart disease in men with low levels of high-density lipoprotein cholesterol. N Engl J Med. 1999; 341(6):410-8. [PubMed: 10438259]

219. Rubins HB, Robins SJ, Collins D, et al. Diabetes, plasma insulin, and cardiovascular disease: subgroup analysis from the Department of Veterans Affairs high-density lipoprotein intervention trial (VA-HIT). Arch Intern Med. 2002; 162(22):2597-604. [PubMed: 12456232]

220. Keech A, Simes RJ, Barter P, et al. Effects of long-term fenofibrate therapy on cardiovascular events in 9795 people with type 2 diabetes mellitus (the FIELD study): randomised controlled trial. Lancet. 2005; 366(9500):1849-61. [PubMed: 16310551]

221. Ginsberg HN, Elam MB, Lovato LC, et al. Effects of combination lipid therapy in type 2 diabetes mellitus. N Engl J Med. 2010; 362(17):1563-74. [PubMed: 20228404]

222. Elam M, Lovato LC, Ginsberg H. Role of fibrates in cardiovascular disease prevention, the ACCORD-Lipid perspective. Curr Opin Lipidol. 2010; 22(1):55-61. [PubMed: 21102326] 
223. Miyazaki Y, Glass L, Triplitt C, et al. Effect of rosiglitazone on glucose and non-esterified fatty acid metabolism in Type II diabetic patients. Diabetologia. 2001; 44(12):2210-9. [PubMed: 11793023]

224. Miyazaki Y, Mahankali A, Matsuda M, et al. Effect of pioglitazone on abdominal fat distribution and insulin sensitivity in type 2 diabetic patients. J Clin Endocrinol Metab. 2002; 87(6):2784-91. [PubMed: 12050251]

225. Miyazaki Y, He H, Mandarino LJ, et al. Rosiglitazone improves downstream insulin receptor signaling in type 2 diabetic patients. Diabetes. 2003; 52(8):1943-50. [PubMed: 12882909]

226. Bajaj M, Baig R, Suraamornkul S, et al. Effects of pioglitazone on intramyocellular fat metabolism in patients with type 2 diabetes mellitus. J Clin Endocrinol Metab. 2010; 95(4): 1916-23. [PubMed: 20157197]

227. Bays H, Mandarino L, DeFronzo RA. Role of the adipocyte, free fatty acids, and ectopic fat in pathogenesis of type 2 diabetes mellitus: peroxisomal proliferator-activated receptor agonists provide a rational therapeutic approach. J Clin Endocrinol Metab. 2004; 89(2):463-78. [PubMed: 14764748]

228. Kubota N, Terauchi Y, Yamauchi T, et al. Disruption of adiponectin causes insulin resistance and neointimal formation. J Biol Chem. 2002; 277(29):25863-6. [PubMed: 12032136]

229. Yamauchi T, Kadowaki T. Physiological and pathophysiological roles of adiponectin and adiponectin receptors in the integrated regulation of metabolic and cardiovascular diseases. Int $\mathrm{J}$ Obes(Lond). 2008; 32(Suppl 7):S13-8. [PubMed: 19136982]

230. Puigserver P, Spiegelman BM. Peroxisome proliferator-activated receptor-gamma coactivator 1 alpha (PGC-1 alpha): transcriptional coactivator and metabolic regulator. Endocr Rev. 2003; 24(1):78-90. [PubMed: 12588810]

231. Coletta DK, Sriwijitkamol A, Wajcberg E, et al. Pioglitazone stimulates AMP-activated protein kinase signalling and increases the expression of genes involved in adiponectin signalling, mitochondrial function and fat oxidation in human skeletal muscle in vivo: a randomised trial. Diabetologia. 2009; 52(4):723-32. [PubMed: 19169664]

232. Brown JD, Plutzky J. Peroxisome proliferator-activated receptors as transcriptional nodal points and therapeutic targets. Circulation. 2007; 115(4):518-33. [PubMed: 17261671]

233. Calnek DS, Mazzella L, Roser S, et al. Peroxisome proliferator-activated receptor gamma ligands increase release of nitric oxide from endothelial cells. Arterioscler Thromb Vasc Biol. 2003; 23(1):52-7. [PubMed: 12524224]

234. Chen NG, Sarabia SF, Malloy PJ, et al. PPARgamma agonists enhance human vascular endothelial adhesiveness by increasing ICAM-1 expression. Biochem Biophys Res Commun. 1999; 263(3):718-22. [PubMed: 10512746]

235. Marx N, Mach F, Sauty A, et al. Peroxisome proliferator-activated receptor-gamma activators inhibit IFN-gamma-induced expression of the T cell-active CXC chemokines IP-10, Mig, and ITAC in human endothelial cells. J Immunol. 2000; 164(12):6503-8. [PubMed: 10843708]

236. Inoue I, Goto S, Matsunaga T, et al. The ligands/ activators for peroxisome proliferator-activated receptor alpha (PPARalpha) and PPARgamma increase $\mathrm{Cu} 2+, \mathrm{Zn} 2+$-superoxide dismutase and decrease p22phox message expressions in primary endothelial cells. Metabolism. 2001; 50(1):311. [PubMed: 11172467]

237. Delerive P, Martin-Nizard F, Chinetti G, et al. Peroxisome proliferator-activated receptor activators inhibit thrombin-induced endothelin-1 production in human vascular endothelial cells by inhibiting the activator protein-1 signaling pathway. Circ Res. 1999; 85(5):394-402. [PubMed: 10473669]

238. Satoh H, Tsukamoto K, Hashimoto Y, et al. Thiazolidinediones suppress endothelin-1 secretion from bovine vascular endothelial cells: a new possible role of PPARgamma on vascular endothelial function. Biochem Biophys Res Commun. 1999; 254(3):757-63. [PubMed: 9920814]

239. Sugawara A, Takeuchi K, Uruno A, et al. Transcriptional suppression of type 1 angiotensin II receptor gene expression by peroxisome proliferator-activated receptor-gamma in vascular smooth muscle cells. Endocrinology. 2001; 142(7):3125-34. [PubMed: 11416035]

240. Dormandy JA, Charbonnel B, Eckland DJ, et al. Secondary prevention of macrovascular events in patients with type 2 diabetes in the PROactive Study (PROspective pioglitAzone Clinical Trial In 
macroVascular Events): a randomised controlled trial. Lancet. 2005; 366(9493):1279-89.

[PubMed: 16214598]

241. Nissen SE, Nicholls SJ, Wolski K, et al. Comparison of pioglitazone vs glimepiride on progression of coronary atherosclerosis in patients with type 2 diabetes: the PERISCOPE randomized controlled trial. JAMA. 2008; 299(13):1561-73. [PubMed: 18378631]

242. Mazzone T, Meyer PM, Feinstein SB, et al. Effect of pioglitazone compared with glimepiride on carotid intima-media thickness in type 2 diabetes: a randomized trial. JAMA. 2006; 296(21): 2572-81. [PubMed: 17101640]

243. Davidson M, Meyer PM, Haffner S, et al. Increased high-density lipoprotein cholesterol predicts the pioglitazone-mediated reduction of carotid intima-media thickness progression in patients with type 2 diabetes mellitus. Circulation. 2008; 117(16):2123-30. [PubMed: 18413496]

244. Nicholls SJ, Tuzcu EM, Wolski K, et al. Lowering the triglyceride/high-density lipoprotein cholesterol ratio is associated with the beneficial impact of pioglitazone on progression of coronary atherosclerosis in diabetic patients: insights from the PERISCOPE (Pioglitazone Effect on Regression of Intravascular Sonographic Coronary Obstruction Prospective Evaluation) study. J Am Coll Cardiol. 2011; 57(2):153-9. [PubMed: 21211686]

245. Nissen SE, Wolski K. Effect of rosiglitazone on the risk of myocardial infarction and death from cardiovascular causes. N Engl J Med. 2007; 356(24):2457-71. [PubMed: 17517853]

246. Simo R, Rodriguez A, Caveda E. Different effects of thiazolidinediones on cardiovascular risk in patients with type 2 diabetes mellitus: pioglitazone versus rosiglitazone. Curr Drug Saf. 2010; 5(3):234-44. [PubMed: 20210732]

247. Sgarra L, Addabbo F, Potenza MA, et al. Determinants of evolving cardiovascular benefit/risk profile of rosiglitazone during the natural history of diabetes. Am J Physiol Endocrinol Metab. 2012; 302(10):E1171-82. Epub 2012 Feb 28. [PubMed: 22374753]

248. Goldberg RB, Kendall DM, Deeg MA, et al. A comparison of lipid and glycemic effects of pioglitazone and rosiglitazone in patients with type 2 diabetes and dyslipidemia. Diabetes Care. 2005; 28(7):1547-54. [PubMed: 15983299]

249. Balakumar P, Rose M, Ganti SS, et al. PPAR dual agonists: are they opening Pandora's Box? Pharm Res. 2007; 56(2):91-8.

250. Tozzo E, Ponticiello R, Swartz J, et al. The dual peroxisome proliferator-activated receptor alpha/ gamma activator muraglitazar prevents the natural progression of diabetes in $\mathrm{db} / \mathrm{db}$ mice. $\mathrm{J}$ Pharmacol Exp Ther. 2007; 321(1):107-15. [PubMed: 17259449]

251. Kendall DM, Rubin CJ, Mohideen P, et al. Improvement of glycemic control, triglycerides, and HDL cholesterol levels with muraglitazar, a dual (alpha/ gamma) peroxisome proliferatoractivated receptor activator, in patients with type 2 diabetes inadequately controlled with metformin monotherapy: A double-blind, randomized, pioglitazone-comparative study. Diabetes Care. 2006; 29(5):1016-23. [PubMed: 16644631]

252. Chira EC, McMillen TS, Wang S, et al. Tesaglitazar, a dual peroxisome proliferator-activated receptor alpha/gamma agonist, reduces atherosclerosis in female low density lipoprotein receptor deficient mice. Atherosclerosis. 2007; 195(1):100-9. [PubMed: 17214992]

253. Liao J, Soltani Z, Ebenezer P, et al. Tesaglitazar, a dual peroxisome proliferator-activated receptor agonist (PPAR alpha/gamma), improves metabolic abnormalities and reduces renal injury in obese Zucker rats. Nephron Exp Nephrol. 2009; 114(2):e61-8. [PubMed: 19887847]

254. Cha DR, Zhang X, Zhang Y, et al. Peroxisome proliferator activated receptor alpha/gamma dual agonist tesaglitazar attenuates diabetic nephropathy in db/db mice. Diabetes. 2007; 56(8):203645. [PubMed: 17536062]

255. Cox SL. Tesaglitazar: a promising approach in type 2 diabetes. Drugs Today (Barc). 2006; 42(3): 139-46. [PubMed: 16628256]

256. Li PP, Shan S, Chen YT, et al. The PPARalpha/ gamma dual agonist chiglitazar improves insulin resistance and dyslipidemia in MSG obese rats. Br J Pharmacol. 2006; 148(5):610-8. [PubMed: 16751799]

257. Henry RR, Lincoff AM, Mudaliar S, et al. Effect of the dual peroxisome proliferator-activated receptor-alpha/gamma agonist aleglitazar on risk of cardiovascular disease in patients with type 2 
diabetes (SYNCHRONY): a phase II, randomised, dose-ranging study. Lancet. 2009; 374(9684): 126-35. [PubMed: 19515415]

258. Ferrario CM, Richmond RS, Smith R, et al. Renin-angiotensin system as a therapeutic target in managing atherosclerosis. Am J Ther. 2004; 11(1):44-53. [PubMed: 14704595]

259. Yusuf S, Gerstein H, Hoogwerf B, et al. Ramipril and the development of diabetes. JAMA. 2001; 286(15):1882-5. [PubMed: 11597291]

260. Barzilay JI, Davis BR, Cutler JA, et al. Fasting glucose levels and incident diabetes mellitus in older nondiabetic adults randomized to receive 3 different classes of antihypertensive treatment: a report from the Antihypertensive and Lipid-Lowering Treatment to Prevent Heart Attack Trial (ALLHAT). Arch Intern Med. 2006; 166(20):2191-201. [PubMed: 17101936]

261. Bosch J, Yusuf S, Gerstein HC, et al. Effect of ramipril on the incidence of diabetes. N Engl J Med. 2006; 355(15):1551-62. [PubMed: 16980380]

262. McMurray JJ, Holman RR, Haffner SM, et al. Effect of valsartan on the incidence of diabetes and cardiovascular events. N Engl J Med. 2010; 362(16):1477-90. [PubMed: 20228403]

263. Van Linthout S, Spillmann F, Lorenz M, et al. Vascular-protective effects of high-density lipoprotein include the downregulation of the angiotensin II type 1 receptor. Hypertension. 2009; 53(4):682-7. [PubMed: 19273745]

264. Olsen MH, Wachtell K, Beevers G, et al. Effects of losartan compared with atenolol on lipids in patients with hypertension and left ventricular hypertrophy: the Losartan Intervention For Endpoint reduction in hypertension study. J Hypertens. 2009; 27(3):567-74. [PubMed: 19262226]

265. Nishida Y, Takahashi Y, Nakayama T, et al. Effect of candesartan monotherapy on lipid metabolism in patients with hypertension: a retrospective longitudinal survey using data from electronic medical records. Cardiovasc Diabetol. 2010; 9:38. [PubMed: 20712859] 


\section{KEY POINTS}

- Lipotoxicity is caused by abnormally high levels of triacylglycerol, nonesterified fatty acid (NEFA), and cholesterol that lead to pathophysiologic conditions in metabolic and cardiovascular (CV) tissues.

- Lipotoxicity-mediated endothelial dysfunction affects tissues, including cardiac muscle, neurons, kidney, skeletal muscle, pancreatic $\beta$-cells, and liver.

- The mechanisms underlying lipotoxicity include oxidative stress, inflammation, mitochondrial dysfunction, and endoplasmic reticulum (ER) stress as well as cell death.

- Treatment with exercise, diet, or pharmacologic agents directly or indirectly reduces lipids in the plasma to ameliorate endothelial dysfunction as well as pathophysiologic conditions in metabolic and CV tissues. 